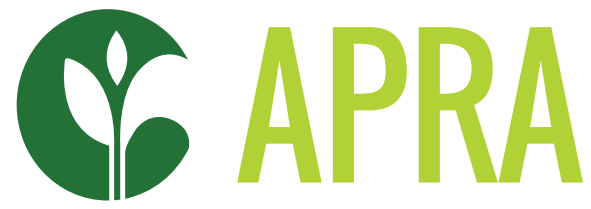

Agricultural Policy Research in Africa

\title{
AGRICULTURAL COMMERCIALISATION AND RURAL LIVELIHOODS IN MALAWI: A HISTORICAL AND CONTEMPORARY AGRARIAN INQUIRY
}

Blessings Chinsinga, Mirriam Matita, Masautso Chimombo, Loveness Msofi, Stevier Kaiyatsa and Jacob Mazalale 


\section{TABLE OF CONTENTS}

Acronyms

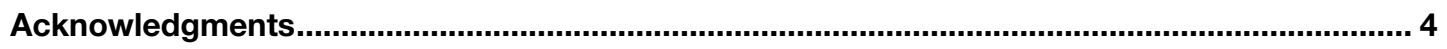

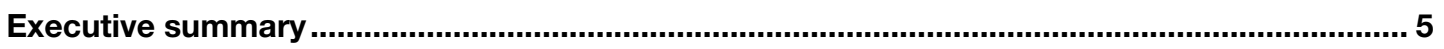

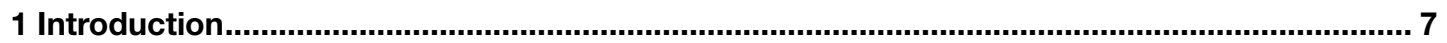

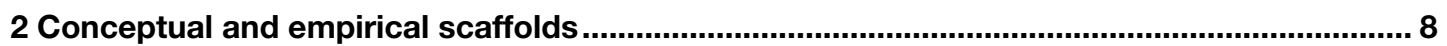

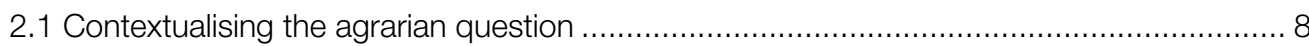

2.2 Historical and contemporary agrarian development in Malawi ....................................... 9

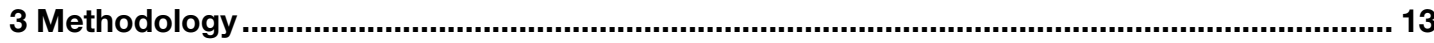

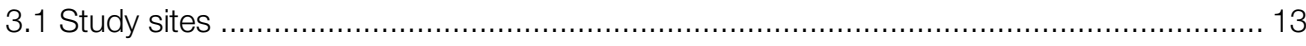

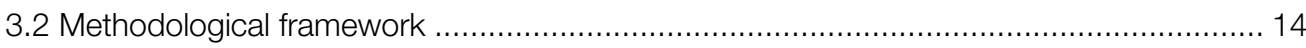

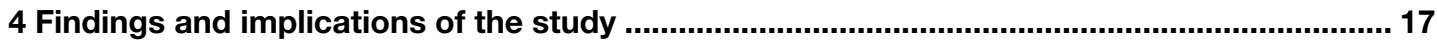

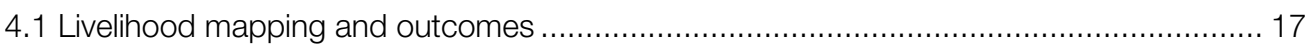

4.2 Socio-economic characteristics of households ........................................................ 18

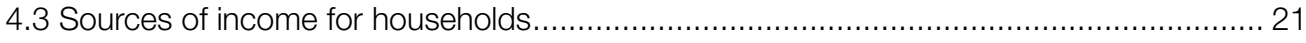

4.4 Production dynamics and agricultural commercialisation ............................................ 22

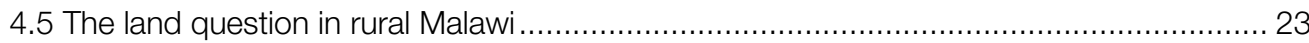

4.6 Social dynamics and agricultural commercialisation ................................................ 25

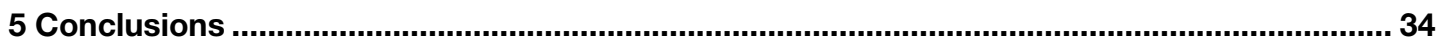

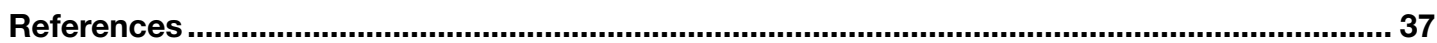

List of tables

Table 3.1: Sample distribution by year and district ......................................................... 15

\section{List of figures}

Figure 3.1: Map of study sites - Mchinji and Ntchisi districts in central Malawi 


\section{ACRONYMS}

\begin{tabular}{|c|c|}
\hline ADMARC & Agricultural Development and Marketing Corporation \\
\hline APRA & Agricultural Policy Research in Africa \\
\hline FGD & focus group discussion \\
\hline FHH & female-headed household \\
\hline FISP & Farm Input Subsidy Programme \\
\hline GVH & Group Village Headman \\
\hline HCl & Household Commercialisation Index \\
\hline IHS & integrated household survey \\
\hline KII & key informant interview \\
\hline LUANAR & Lilongwe University of Agriculture and Natural Resources \\
\hline MASFA & Mchinji Area Smallholder Farmers Association \\
\hline MHH & male-headed household \\
\hline NAP & National Agricultural Policy \\
\hline NASFAM & National Association of Smallholder Farmers of Malawi \\
\hline NGO & non-governmental organisation \\
\hline NSO & National Statistics Office \\
\hline SACA & Smallholder Agricultural Credit Administration \\
\hline SAP & Structural Adjustment Programme \\
\hline T/A & Traditional Authority \\
\hline
\end{tabular}




\section{ACKNOWLEDGEMENTS}

We would like to take this opportunity to thank all the people who participated in this study. At a national level, we engaged with policymakers, development partners, farmers' organisations, and non-governmental organisations (NGOs) while at the district level we interacted with district agricultural officials from district councils and NGOs in Mchinji and Ntchisi. These engagements, especially through feedback sessions of our preliminary findings, were critical in helping us refine, deepen, and broaden our understanding of the underlying processes of agricultural commercialisation in both historical and contemporary contexts. We are grateful to the Traditional Authorities (T/ As), Group Village Headmen (GVH) and Village Headmen; extension workers, lead farmers and ordinary farmers (both men and women) who took the time to share their insights in both the focus group discussions (FGDs) and life history interviews. We also extend a debt of gratitude to John Thompson and Imogen Bellwood-Howard for the technical support and guidance they provided during the conceptualisation, execution and writing up of the report. We also thank all our research assistants and the APRA consortium members that directly contributed to this study's success including Cyriaque Hakizimana, the regional Hub coordinator. We dedicate this work to the late Ephraim Wadonda Chirwa who was very instrumental in the conceptualisation of this study, and may his soul continue resting peace.

Blessings Chinsinga, PhD is a Professor at the Department of Politics and Government and an outgoing Director for the Centre for Social Research at the University of Malawi. Mirriam Matita, who holds a Master of Arts in Economics from the University of Malawi, is an academic staff member at the Lilongwe University of Agriculture and Natural Resources (LUANAR) in the Department of Extension and Rural Development. Masautso Chimombo is a Lecturer in Rural Sociology and the Deputy Head of Department in the Extension and Rural Development Department at LUANAR. Loveness Mgalamadzi is a Lecturer in Extension and Rural Development at LUANAR and is a PhD candidate at the University of the Western Cape in South Africa. Stevier Kayiyatsa, who holds a Master of Science in Agricultural and Applied Economics jointly offered by the University of Malawi and the University of Pretoria, is a Principal Economist in the Ministry of Economic Planning, Development and Public Sector Reforms in Malawi. Jacob Mazalale, PhD is a Lecturer in Health Economics and the Deputy Head of the Department of Economics at the University of Malawi. Ephraim Chirwa, PhD was a retired Professor of Economics from the University of Malawi, who until his passing in July 2019, was the Managing Director of Wadonda Consult Limited.

This working paper is funded with UK aid from the UK government (Foreign, Commonwealth \& Development Office - FCDO, formerly DFID). The opinions are the authors and do not necessarily reflect the views or policies of IDS or the UK government. 


\section{EXECUTIVE SUMMMARY}

This study was carried out to understand the underlying dynamics of agricultural commercialisation in Malawi, especially among smallholder farmers. Despite various concerted efforts to accelerate agricultural growth and transformation, the progress among smallholder farmers has been less satisfactory. Most of the smallholder farmers do not engage with markets on a consistent and sustainable basis. Consequently, the aim of this paper was to demonstrate that there is no one ideal type of agricultural commercialisation that can be realised through investment and policy intervention. People engage with processes of agricultural commercialisation along value chains, from production to processing to marketing in a variety of ways. A total of 240 households were interviewed in the 2006/07 growing season as part of the evaluation of the Farm Input Subsidy Programme (FISP) in the Mchinji and Ntchisi districts. These households were resurveyed in the 2018/19 growing season after a tenyear period to understand their experiences with the processes of agricultural commercialisation.

In this study we used a mixed-methods approach with data collection spanning a period of three years. We first conducted a reconnaissance survey at the national, district and local levels to give a snapshot of historical and contemporary perspectives of the two districts' experiences with agricultural commercialisation. Next, we used a quantitative tracker survey, which targeted all households in the Mchinji and Ntchisi sub-dataset who were interviewed by the School of Oriental and African Studies (SOAS) et al. (2008) at baseline, as well as branching out households emerging from the original 240 households. Finally, we employed a life history method targeting 120 households, which we categorised into five different livelihood trajectories: stepping out, stepping up, hanging in, dropping out and stepping in. The data were analysed and interpreted using quantitative and qualitative tools of analysis to assess the agricultural commercialisation situation in rural Malawi. The quantitative techniques used were descriptive statistics such as means and frequencies, correlation and regression analyses and thematic analysis was used for the qualitative component of the study.
The results of the study show that agricultural commercialisation is a complex process marked by a wide range of cyclic continuities and discontinuities over time. The pattern and rhythm of these continuities and discontinuities are shaped by the overall operative context including political, economic, social, and cultural dimensions. These play a critical role in determining the form of the agrarian transformation that takes place. Consequently, agricultural commercialisation cannot be reduced to a predictable universal blueprint since there are multiple pathways to commercialisation even for households that seemingly fall into the same livelihood trajectories. Nevertheless, agricultural commercialisation occurs when agricultural enterprises and/or the agricultural sector as a whole rely increasingly on the market for the sale of produce and for the acquisition of production inputs, including labour. Credible agricultural commercialisation happens when farmers are pulled out of the farm into viable non-farm activities and not pushed off the farm into low-paying desperation jobs due to the inability of local agriculture to provide a reasonable standard of living (Jayne et al., 2011).

The message from this study is that life in rural Malawi is tough; agriculture is no longer reliable as an exclusive means of subsistence and must be supplemented with other livelihood strategies, especially given the rapidly diminishing land per capita and worsening climatic conditions. The results further show that, most of the households that belong to the stepping out, stepping up and stepping in livelihood trajectories, are predominantly male-headed households (MHHs) with both spouses available. Female-headed households (FHHs) are clearly outnumbered; most of them belong to either hanging-in or dropping out livelihood trajectories. There are, of course, exceptions, but the findings from this study show that $\mathrm{FHH}$ are subjected to multiple deprivations and disadvantages. These make it difficult for the FHHs to effectively participate in agricultural commercialisation activities. There is a great deal of gender and social differentiation manifested through access, control and use of land; asset accumulation, social networks, or capital; and access to markets. FHHs' challenges are exacerbated by cultural norms 
or expectations that women should be subservient to men and limit their activities outside the homestead within the neighbourhood unless specifically granted permission. These constraints make it very difficult for women to benefit from bridging social networks that are a proven source of greater information diffusion than bonding social networks. The results of the study also show that women and other disadvantaged families are consistently disadvantaged in terms of access to productive resources such as credit, skills and information, social capital, especially in terms of leadership and access to opportunities mediated by external actors.

The dynamics of agricultural commercialisation in rural Malawi have been negatively affected by the triple crisis of land, productivity and marketing. Land tenure security remains uncertain due to an unsettled legislative framework. Productivity levels of various crops have remained far below the expected thresholds due to the combination of limited ability to access productivity enhancing inputs - especially seed and fertiliser - and worsening climatic conditions. Since the collapse of the Agricultural Development and Marketing Corporation (ADMARC) as a reliable marketing outlet, smallholder farmers have also found it extremely difficult to sell their produce at a profit. Smallholder farmers have engaged with these challenges in different ways. Some have sold off their land to the emerging urban farmers; some have found ways of acquiring additional land while others have mounted resistance to protect their land through politically influential traditional leaders. Smallholder farmers have also diversified their livelihood portfolios to hedge themselves against declining productivity through, for instance, crop diversification, off-farm activities, and increasing the amount of land under winter cultivation. Through often externally-driven efforts, smallholder farmers have organised themselves into cooperatives to enhance their bargaining powers with buyers of their produce and in the worst-case scenario, they have reacted to the unscrupulous business tendencies of the buyers by selling rotten or poor-quality produce.

In tandem with insights from the critical agrarian scholarship, the experiences of smallholder farmers in rural Malawi highlight continuity, change and relentless challenges in their efforts to earn their respective livelihoods in a context shaped by both internal and external forces. These experiences underpin Berry's (1993) conclusion that no condition is permanent. The experiences of the smallholder farmers reported in this study demonstrate that land tenure systems, access mechanisms, labour and market relations, individual and collective choices, strategies and priorities, even communal relationships and social units are in constant state of flux, and at times subject to some contestation and negotiation. Related to this is the fact that rural communities are not homogenous. They experience the same stimuli differently depending mainly on their social and kinship status, material endowment, age and even gender. The experiences of these communities also show that these positions are not static. Rural households have the power to alter their fate, but this is largely dependent on how they exercise their agency subject to the influence of both endogenous and exogenous forces.

These results highlight the fact that context matters in understanding the dynamics of agricultural commercialisation. Politics from below and from above are critical in shaping the underlying dynamics of agricultural commercialisation. Policy decisions at the national level are critical to shaping the dynamics of agricultural commercialisation subject to the strategic engagements from local communities depending on the perceived intent of the policies. Local communities are not passive recipients of national policies; they either contest or appropriate them in ways that would promote or safeguard their interests, however irrational it may appear to the outsiders. These results also highlight the question of scale in local level development and transformation. They suggest that it is important to consider a problem at multiple scales, allowing common elements across scales to be identified as well as the key features of the problem at each scale. The issue of agricultural commercialisation in rural Malawi, for instance, is shaped by a combination of forces operating at the global, national and local levels. Understanding the dynamics at each level and how they interact is key to achieving transformative and sustainable solutions to pressing contemporary political, economic, social and even cultural challenges.

The conclusion of this study is that changes in the overall operative context have had a significant impact on land access and ownership, patterns of accumulation and investment, gender, and social differentiation. Agricultural commercialisation is not a significant determinant in shaping and influencing farmers' livelihood trajectories, but is nonetheless a key temporal driver in improving household welfare, housing conditions, and children's education through market participation and engagement. This is because farmers are unable to participate in and engage with lucrative markets on a sustainable basis. The ad hoc nature in which smallholder farmers participate in and engage with markets makes it very difficult to guarantee sustainable poverty escapes and household prosperity. Consequently, most of the farmers in the two districts are essentially 'hanging-in', unable to meet and cross production thresholds that would enable them to diversify their livelihood portfolios through agricultural commercialisation and agrarian transformation. 
This study was inspired by APRA's perspective that there are diverse ways that people engage with processes of agricultural commercialisation along value chains, from production to processing to marketing. Much of the debate around commercialisation offers simplistic dichotomous comparisons between, for example, large- and small-scale farming, or export oriented and domestic markets. Yet, in reality, agricultural commercialisation is far more complex.

For the purposes of this paper, agricultural commercialisation is understood as occurring when agricultural enterprises and/or the agricultural sector as a whole rely increasingly on the market for the sale of produce and for the acquisition of inputs, including labour (Poulton, 2017). It is an integral and critical part of the process of structural transformation through which a growing economy transitions over a period of several decades or more. This implies that farmers intensify their use of technology-enhancing inputs, achieve greater output per unit of land expended, produce greater surpluses, expanding their participation in markets, and ultimately raise their standard of living. Credible agricultural commercialisation happens when farmers are pulled off the farm into viable non-farm activities and not pushed into low-paying desperation jobs due to the inability of local agriculture to afford a reasonable standard of living (Jayne et al., 2011).

This study was inspired by the critical agrarian literature of scholars such as Kerkvliet (2009), Kay (2008), Berry (1993) and Bernstein (1982). The overarching goal of critical agrarian scholarship is to understand the underlying logic of how peasants are incorporated or integrated into the capitalist mode of agricultural production over time. The key argument is that variations notwithstanding across historical epochs, peasants have always been incorporated or integrated into capitalist modes of production on unfair or exploitative terms. Even when policy pronouncements unequivocally advocate for radical changes in terms of peasants' engagement, the exploitative tendencies against them tend to persist. Peasants are rarely winners; they are often exploited in one way or another.

The situation of smallholder farmers in Malawi has been worsened by the increasing commodification of land in the context of a contentious land legislative framework. A new land legislative framework was finalised in November 2016, but it remains a subject of continued contestation, especially in relation to customary land. The uncertainties in the definitiveness of the land legislative framework are catalysing massive land sales, particularly among those who are poor and destitute. This is leading to a new wave of destitution and proletarianization of the rural masses, particularly in those districts that are within $120 \mathrm{~km}$ radius from the capital city, Lilongwe (Answeeuw et al., 2016; Chinsinga, 2018; Chinsinga and Matita, 2021). In addition, for households getting into agriculture, land is a major constraint (Matita et al., 2021).

The remainder of the paper is organised as follows: Section 2 is divided into two main parts. The first part provides a brief overview of the critical agrarian scholarship that inspired the conceptualisation and implementation of the study as well interpretation of its findings. The second part sets the context of the study by providing a brief historical and contemporary agrarian development in Malawi. Section 3 provides a brief description of the study sites and outlines the methodological framework used for data collection. Section 4 presents key findings of the study and section 5 offers some concluding remarks and reflections. 


\subsection{Contextualising the agrarian question}

The agrarian question has been and continues to be a subject of intense study across several disciplines including political science, political economy, sociology, anthropology, and agriculture. The agrarian question mainly focuses on understanding the underlying logic of how peasants have been incorporated or integrated into the capitalist mode of agricultural production over time. The underlying argument is that regardless of the variations across historical epochs, peasants have always been incorporated or integrated into the capitalist agricultural modes of production on unfair or outright exploitative terms.

According to Speijer (2016), agrarian development and transformation is a multi-dimensional process of how farming systems adapt to change in the context of the interplay of knowledge, technologies, ideas, and markets. Triggers of agrarian development and transformation include: 1) land use intensification; 2) economic diversification; 3) institutional change; 4) demographic transition; and 5) fragility of commodification. This suggests that agrarian development and transformation is a function of several different drivers that structure everyday life and decision-making. These decisions have real and visible effects acting to change the structural conditions of farming mediated by social institutions. It is against this backdrop that the following are touted as the key criteria for understanding the state of agrarian development and transformation in each society: 1) the nature of society in question; 2) its populationenvironment relationship and pressures on resources; 3 ) its history in engaging in commodity markets and levels of knowledge; and 4) other aspects of political and economic history (CICRED, 2007).

Most studies critical to understanding the agrarian question have engaged with the broader understanding of agrarian development and transformation using historical and contemporary perspectives (Bernstein, 1982; Berry, 1993; Borras, 2009; Kerkvliet, 2009; Scoones, 2009). There are three themes that run through these works, namely: continuity, change and challenges. According to Berry (1993), this is inevitable because no condition is permanent, and the rural communities are never homogenous. They may include the landed, landless, rural labourers, migrant workers, forest dwellers, subsistence fishers, indigenous people, pastoralists, women, and youth-headed households, traditional social and political elites etc.

Throughout the colonial and postcolonial history, Berry (1993) argues that peasants have creatively and proactively engaged with external agents to advance and protect what they believe to be in their best interest. Her work challenges long-held assumptions that African socio-cultural and political networks are static, demonstrating that they are quite flexible and responsive to changing political realities and circumstances over time. Jallow (undated) observes that through her work, Berry (1993) paved the way for scholars to pay particular attention to episodes of organised collective peasant resistance to direct assaults by colonial and postcolonial states on their property or labour. The imagery of rural economies and societies as a shifting display of conflicts, alliances and manoeuvres denotes the inherent difficulty of establishing who exactly is in control. This is the basis for Berry's (1993) conclusion that no condition is permanent. Land tenure systems, access mechanisms, labour and market relations, individual and collective choices, strategies and priorities, even communal relationships and social units are in a constant state of flux, and subject to contestation and negotiation according to time and circumstance. In these communities, personal interactions are often characterised by negotiation and manipulation of kin, economic, political, and social networks.

A critical analysis of the agrarian scholarship debate yields two contending theoretical positions on rural development: residual and relational. The former is based on the belief that the cause of poverty of the rural poor is their being excluded from the market and its benefits while the latter stresses that the cause of poverty is the very terms of poor people's insertion into patterns of social relations. These perspectives imply radically different interventions to address the plight of the rural poor. For the residual perspective, the solution is to bring the market to the rural poor, or the rural poor to the market while for the relational perspective, 
the solution is to restructure existing social relations through transformative policies and political processes. The relational perspective has become the basis for agrarian populism, which is essentially against the pressures exerted by the class agents of developing property and agrarian capital and indeed projects of state-led national development in all their capitalist, nationalist, and socialist variants. The moral dimension of agrarian populism as a defence of a threatened and idealised way of life encompasses strong elements of anti-industrialism and anti-urbanism (Bernstein, 2009).

There has been tremendous intellectual engagement regarding the fate of peasants in agrarian development and transformation. The contestations notwithstanding, rural communities have demonstrated agency and resilience while grappling with a similar set of problems whose nature and scope have been changing in response to changing circumstances. Jallow (undated) observes that the optimal strategy for many rural people has been to increase diversity of their social networks and clientage to cope with the instability of resource allocation, labour availability and pricing. The possibilities for successful economic development hinges on outsiders' appreciation of this diversity, flexibility, and change that characterise African communities (Jallow, undated; Berry, 1993). This calls for a detailed analysis of the contradictory sources and impulses and multi-class character of rural struggles in a historical and contemporary perspective. It also reinforces the need to systematically look at the trajectory of political, economic, social, and cultural forces that determine or limit agrarian transformation (CICRED, 2007).

There are several concepts that are very important to understanding the underlying dynamics of agrarian societies. Social relations, class and social networks provide useful lens for comprehending the state of an agrarian society at any point in time. Social relations are defined as structured and systematic interactions of different social groups and individuals within those groups for production, exchange, consumption and reproduction, which are governed by institutions such as markets, states, civil society and households (Tsikata, 2015). The idea of intersectionality is very central to understanding the implications of social relations on the livelihoods of the people. The main thrust of intersectionality is that different social relations intersect and interlock in complicated ways, reinforcing or qualifying privilege, advantages, hierarchies, inequalities, and disadvantages (Crenshaw, 1989; Tsikata, 2015).

The notion of class is particularly important because the pattern of accumulation continuously interacts with the nature of class relations in an agrarian economy
(Bhaduri, 1981). This interaction is a two-way process as at any given time the existing class configuration influences the process of accumulation, which, in turn, affects the evolving relations among classes. Olofsson's (2020) perspective on class analysis is quite illuminating. He challenges the view that smallholder farmers are largely undifferentiated as if they are economically, socially and politically homogeneous. There is thus need to deconstruct the stereotype of the smallholder farmer as a homogenous group so as to better understand socioeconomic differentiation processes and vulnerabilities and inequalities resulting from them.

Sobel (2002) describes social networks as an investment people make and maintain with an eye towards current or future benefits. The distinction between bonding and bridging social networks is particularly important. The former develops in the same sub-group often between family members, neighbours and friends while the latter develops from ties between sub-groups or different actors, for instance, between acquaintances. These social networks play different roles: bonding networks represent high levels of trust where actors believe in other to act in an agreed manner and plays a positive influence, for example, in the adoption of technologies whereas bridging networks are crucial to providing access to resources and opportunities that do not exist within a closed circle of friends, family or neighbourhood (Bourne, et al., 2017).

\subsection{Historical and contemporary agrarian development in Malawi}

Malawi's agrarian development and transformation is a complex one. It has its origins in the colonial era although there have been tremendous changes since independence in 1964. There are several scholars who assert that Malawi's colonial past has greatly influenced its agrarian development, underpinned by patterns of continuities and discontinuities that reflect efforts to either perfect the colonial heritage or to take a completely new trajectory of agrarian development and transformation (Kydd, 1984; Chipande and Vaughan, 1986; Green, 2007; Green, 2011). The underlying argument is that the end of colonialism is not identified as a historical break, simply because it is not supported by distinct long-term rhythms of policy and practice as well as agricultural growth.

The country's transition from a one-party dictatorship to a multiparty political dispensation created possibilities for dramatic change in agricultural policy that would favour smallholder farmers as a dominant voting bloc (Poulton and Chinsinga, 2018). Several reviews indicate that the policy environment is still 
skewed against the interests of smallholder farmers even when policy pronouncements are made in their favour (Chinsinga, 2012; Chinsinga, 2018; Mangani et al., 2020). This is partly attributed to the competitive, clientelistic political settlement that has seen political elites predominantly prioritising policies not because of what the policies can do for the country but rather because of the benefits and privileges, or alternatively rent-seeking opportunities, the implementation of these policies would generate (Chinsinga and Matita, 2021; Chinsinga and Mwalukumo, 2021). Several key elements of the colonial agrarian heritage that have had a lasting influence on the country's agricultural development and transformation include: the bifurcated or dualistic nature of the agricultural state into estate and smallholder sub-sectors; the land tenure system; and the crop produce marketing system (Kydd, 1984; Chinsinga, 2007; Green, 2011). The limited success in addressing these challenges has deepened and worsened the agrarian crisis in Malawi. The key elements of this crisis include: 1) the productivity crisis; 2) the land crisis; and 3) the marketing crisis.

\subsubsection{The productivity crisis}

Several accounts attribute the productivity crisis in Malawi's agriculture to the bifurcated or dualistic nature of the agricultural sector inherited from the British colonial administration (Chirwa and Zakeyo, 2004; Green, 2011; Chirwa and Matita, 2015). The main trigger of the productivity crisis is regarded as the differential treatment that was accorded to the estate and smallholder sub-sectors. The primacy of the smallholder sector as a driver of agricultural growth and development was abandoned in the first five years of independence due to it being inefficient and ineffective (Green, 2007; Green, 2011; Chinsinga, 2018). The estate sector, dominated by influential people such as chiefs, senior servants, senior parastatal employees, security officials (Malawi Young Pioneers, Malawi Police Service and Malawi Defence Force) and leading entrepreneurs, and championed by Malawi's founding president, Dr. Banda, was accorded preferential treatment in terms of access to credit facilities, extension services, land, and cheap labour. This preferential treatment was especially entrenched through legislation. Unlike smallholder farmers, the estate sub-sector under the aegis of the Special Crops Act 1963, exercised a monopoly over the cultivation of lucrative crops such as burley tobacco, coffee, tea, and sugar (Chinsinga, 2002; Chirwa and Zakeyo, 2004).

While the consistent implementation of subsidies since the late 1980s may seem like good news for smallholder farmers, these subsidies were not primarily driven by the desire to improve their welfare but rather to create opportunities for rent seeking through procurement, distribution, and transportation of inputs (Chinsinga, 2012). The implementation of the subsidies mainly benefits people with political connections. Further analysis of the expenditure portfolio of the subsidies show that the Ministry of Agriculture devotes about 75 per cent of its budget to buy farm inputs at the expense of key public sector investments for accelerated agricultural development (Chirwa and Dorward, 2013; Chirwa and Matita, 2015). Investment in research, extension, and infrastructure (rural roads, irrigation facilities, electricity etc.) is minimal or nonexistent (Kambewa et al., 2018). Smallholder farmers are major losers since despite being beneficiaries of these subsidies, they are unable to produce enough and are often victims of chronic almost on a yearly basis.

The productivity crisis in the smallholder sector has been further worsened by the huge gender productivity gap. While this gender gap is a widespread problem across sub-Saharan Africa, it is quite pronounced in Malawi (UN Women et al., 2015). It is estimated that the gender gap in agricultural productivity measured by the value of agricultural produce per unit of cultivated land ranges from 4 to 25 per cent, depending on country and crop. Palacio-Lopez and Lopez (2015) show that agricultural labour productivity in Malawi is on average 44 per cent lower on plots managed by females than those managed by male heads of households. They further observe that 34 per cent of this gap is explained by differences in labour market access and 29 per cent by differences in credit access and 29 per cent by differences in credit. Cook et al. (2014) make similar observations. The gender productivity gap is huge because women farmers have less access to credit and are less able to command labour, relying more on their own labour and that of their children.

The productivity crisis explains the daunting livelihood challenges in Malawi. Poverty remains widespread and inequalities between the rich and the poor continue to deepen and widen. According to the 2016/17 Integrated Household Survey (IHS), there has been no change in moderate poverty nationally and in urban areas, but poverty has increased in rural areas. In 2010/11, the incidence of rural poverty was estimated at 56.6 per cent, but spiked to 59.5 per cent in 2016/17 (NSO, 2019). At the national level, the incidence of poverty has significantly declined from 65 per cent in 2001 to about 51.5 per cent in 2016/17. While about half of Malawians live below the poverty line, the poverty situation is quite pronounced in rural areas at 59.5 per cent. The situation has not significantly changed. According to Drazi et al. (2020), the percentage of households that reported that they had very low food security in the week leading up to the fifth IHS dropped but remained high in 2019 (31.1 per cent in 2010; 39.6 per cent in 
2013; 55.7 per cent in 2016 and 52.2 per cent in 2019). This deeply entrenched poverty constrains many households from realising their potential.

\subsubsection{The land crisis}

Malawi's land legislative framework is in a state of flux which is mainly attributed to the failure to reform the land tenure system inherited from the British colonial government (Ng'ong'ola, 1982; Kanyongolo, 2005; Chinsinga, 2008). Instead of implementing extensive land reforms, the Malawi Congress Party government simply inherited the colonial land tenure system with minor modifications. The postcolonial government continued with a tenure system that distinguished land into three categories: customary, private, and public land.

The post-independence land reforms were motivated by Malawi's first president's desire to revolutionise the country's agriculture and transform it from a poor one into a rich one. These reforms were further instigated by the relative superior performance of the estate sector. Estate production grew at an average annual rate of 6.6 per cent from 1964 to 1969 while the growth of output on smallholder farms was a mere 2.1 per cent per year (Dickermand and Bloch, 1991; Green, 2011). This prompted the government to pursue a policy that promoted one-way transfer of land from the customary sector to the estate sector usually with little or no compensation at all.

The transition to democracy in May 1994 offered an opportunity to put the land reform question on the agenda. A presidential Commission on Land Inquiry was established in 1996 to develop a roadmap that would guide the post one-party land reforms efforts. The commission concluded its work in 1999 (Peters and Kambewa, 2007) and a new land policy was adopted in 2002. The key feature of this policy was that it distinguished two categories of land, namely: private and public. Several initiatives were undertaken to pilot the policy, notably, through the Community Based Land Redistribution Programme supported by the World Bank (Chinsinga, 2008; Chirwa, 2008). After protracted debates and contestations about the robustness of the outcomes of this project under the Malawi Land Reform Implementation Programme, the experiences of the pilot were used to inform the development of 10 land-related laws that were adopted by parliament in November 2016. The major bone of contention was specifically the Customary Land Act. The reclassification of land into two from the three previous categories meant that customary land was considered vacant and unallocated. The implication of this reclassification is that customary claims of landholders who occupy or use the land are not recognised in law or practice, which has turned out to be the main basis for conflicts (Kanyongolo, 2005; Chinsinga and Chasukwa, 2015; Chinsinga, 2018).

The protracted delays in establishing a definitive land legislative framework have had its own challenges. Some policies that the government has signed up to have opened the country up to foreign land grabs (Chinsinga and Chasukwa, 2015). Through the Green Belt Initiative, the government explicitly states it will facilitate the acquisition of land for private investors, but it does not indicate where this land will come from and how exactly it will be acquired. In its ascension to the G8 New Alliance for Food Security and Nutrition, the government committed itself to adopt a new land bill and conduct a survey to identify unoccupied land, both customary and leasehold, as well as to determine crop suitability with the view to setting aside 200,000ha for large-scale commercial agriculture by 2018 (Orama and Wijertna, 2014). This period of impasse has further coincided with the rise in medium-scale farms. According to Anseeuw et al. (2016), 54 per cent of these farms have resulted from the accumulation of land by small-scale farmers while the remainder (46 per cent) are acquisitions by urban-based professionals, entrepreneurs, and public sector workers. Through this agricultural growth trend an increasing number of smallholder farmers are losing their land, as they are selling it off and being displaced by this new class of farmers, who do not farm full-time and are often urban based (Chinsinga and Matita, 2021). While customary land is projected as something which cannot be sold in the local discourses, land markets for this type of land have existed for a very long time now. Chimhowu and Woodhouse (2006) denotes these markets as 'vernacular' land markets.

\subsubsection{The marketing crisis}

The marketing crisis is related to the reforms that have been undertaken to the agricultural sector since the turn of the 1980s under the auspices of the International Monetary Fund and World Bank supported Structural Adjustment Programme (SAP) reforms. Malawi was one of the first few African countries to be subjected to SAPs following the World Bank 1981 Berg report, which argued that developing countries were experiencing serious economic problems because they overextended their state machineries (Chilowa, 1991; Chinsinga, 2002; Chilowa and Chirwa, 1997). The underlying argument was that the state in the developing world had taken on too many responsibilities to be effective in the sphere of development and transformation. It therefore needed to roll back its involvement, especially in the productive sectors of the economy such as transport, health, education, agriculture, housing and concentrate its 
efforts on providing an enabling environment for economic agents through facilitation and regulation (Chilowa, 1991; Oya, 2010).

This paradigm shift influenced the nature and scope of the reforms implemented in the country's agricultural sector (Chinsinga, 2004). Part of the reforms within the agricultural sector targeted the produce marketing board, namely ADMARC. This involved a management reform, closure of its uneconomic marketing outlets and liberalisation of the marketing of smallholder crops (Christiansen and Stackhouse, 1989). The decision to liberalise the marketing of smallholder produce culminated in the 1987 Agricultural Marketing Act, which allows private traders to participate in the marketing of agricultural produce. These reforms also included the liberalisation of the cultivation of burley tobacco to smallholder farmers. This was justified to improve farmers' access to cash income, which would not only generally improve their livelihoods but also food security. With increased disposable income from the sale of burley tobacco, smallholder farmers would be able to meet their food security obligations as they would be able to purchase food from the market and not even need to grow their own food (Masanjala, 2006; Prowse and Grassin, 2020).

Three decades later, smallholder farmers in rural Malawi struggle to market their produce at a profit. Such markets do not exist because the assumption that the vacuum created by the withdrawal of ADMARC, which had a network of markets across the country, would be taken up by the private sector has not yet materialised. A viable replacement to the ADMARC marketing arrangements is yet to be found. The private sector has not been able to rise to the challenge because of the substandard state of road infrastructural networks in most rural areas. Private sector produce buyers often restrict themselves to readily accessible areas 'because for start-up entrepreneurs and even established ones, it is financially too risky or unprofitable to operate in the remote parts of the country' (Owusu and N'gambi, 2002, p. 20). This is not surprising because over the years a disproportionate share of resources in the agricultural sector have been devoted to the procurement of inputs for subsidies at the expense of substantive investment in vital public goods such as infrastructure, research, and extension.

Several efforts have been undertaken to improve the marketing infrastructure for smallholder agricultural produce. Most of these initiatives have generally been driven by the non-state actors and development partners with the state playing hugely a facilitating role. NGOs, working with some state functionaries, have promoted the development of clubs, associations and even cooperatives (Chimombo, 2018). The aim of these initiatives is to improve the marketing capacity of smallholder farmers through collective bargaining. The success of these initiatives has been limited due to, among other things, widespread poverty among most of the farmers who would want to sell their produce as quickly as possible to meet basic survival needs, and the failure of most of these organisations to find viable markets, especially if they are working on their own without linkages to any institution.

\subsubsection{Implications of the triple crises}

There have been considerable twists and turns in Malawi's agrarian story since independence in July 1964. The story, influenced and shaped by both internal and external forces, has not been very favourable to the progressive, transformative, and sustainable development of smallholder farmers in the country. While the smallholder farmer has not been a passive actor, the weight of external forces even after the transition to democracy in May 1994, has limited his or her options. Smallholder farmers have been consistently on the losing side which has made it difficult for them to actively shape and influence their destiny (Chinsinga, 2018).

The triple crise of productivity, land, and marketing are a direct result of policy decisions that are often projected in the name of the smallholder farmer but are designed and implemented to serve the elite's own interests. The reforms implemented in the agricultural sector in the context of SAPs have worsened the operative context of smallholder farmers over the past three decades. The country, for instance, does not have a viable domestic seed industry; farm inputs have become unaffordable to most of the farmers; access to extension services by farmers has greatly diminished; and the incidence of poverty and food insecurity among smallholder farmers has been worsening. While in the heydays of ADMARC smallholder farmers had access to a ready and predictable market, ADMARC 'taxed' farmers through pan territorial pricing and the 'profits' were never invested in smallholder agriculture, and were instead used to subsidise estate agricultural development (Chirwa and Matita, 2015; Kambewa et al., 2018). 


\subsection{Study sites}

This study was conducted in the Mchinji and Ntchisi districts in central Malawi. Maps of these study sites are presented in Figure 3.1. These districts are located approximately $110 \mathrm{~km}$ and $90 \mathrm{~km}$ from Lilongwe, the capital of Malawi, respectively. They are both part of the Lilongwe-Kasungu plain, which is considered more favourable to crop production than most areas in the country (Asfaw et al., 2017). Tobacco is the main cash crop in both districts. Other significant crops include groundnuts, soya beans, sweet potatoes and maize which are mainly sold to Lilongwe and surrounding trading centres.

The major distinguishing feature between Mchinji and Ntchisi is that the former shares borders with both Mozambique and Zambia, the distance to the nearest border locations being $300 \mathrm{~km}$ and $10 \mathrm{~km}$, respectively. The Zambian border offers Mchinji residents an opportunity to engage in cross-border livelihood strategies through formal and informal trade, migration, and casual work, particularly during the lean agricultural season. The cross-border livelihood activities are further facilitated by the existence of a railway line between the districts of Mchinji and Chipata in Zambia. According to Chirwa and Matita (2015), Zambia offers a more lucrative alternative outlet for farmers, especially those engaged in the cultivation of horticultural crops. In terms of development infrastructure and business activities Mchinji is far more vibrant than Ntchisi.

Livelihoods in rural Malawi are becoming increasingly fragile due to the worsening climate change situation (Chinsinga and Chasukwa, 2018). According to the World Bank (2010), Malawi ranks as the world's

Figure 3.1: Map of study sites - Mchinji and Ntchisi districts in central Malawi

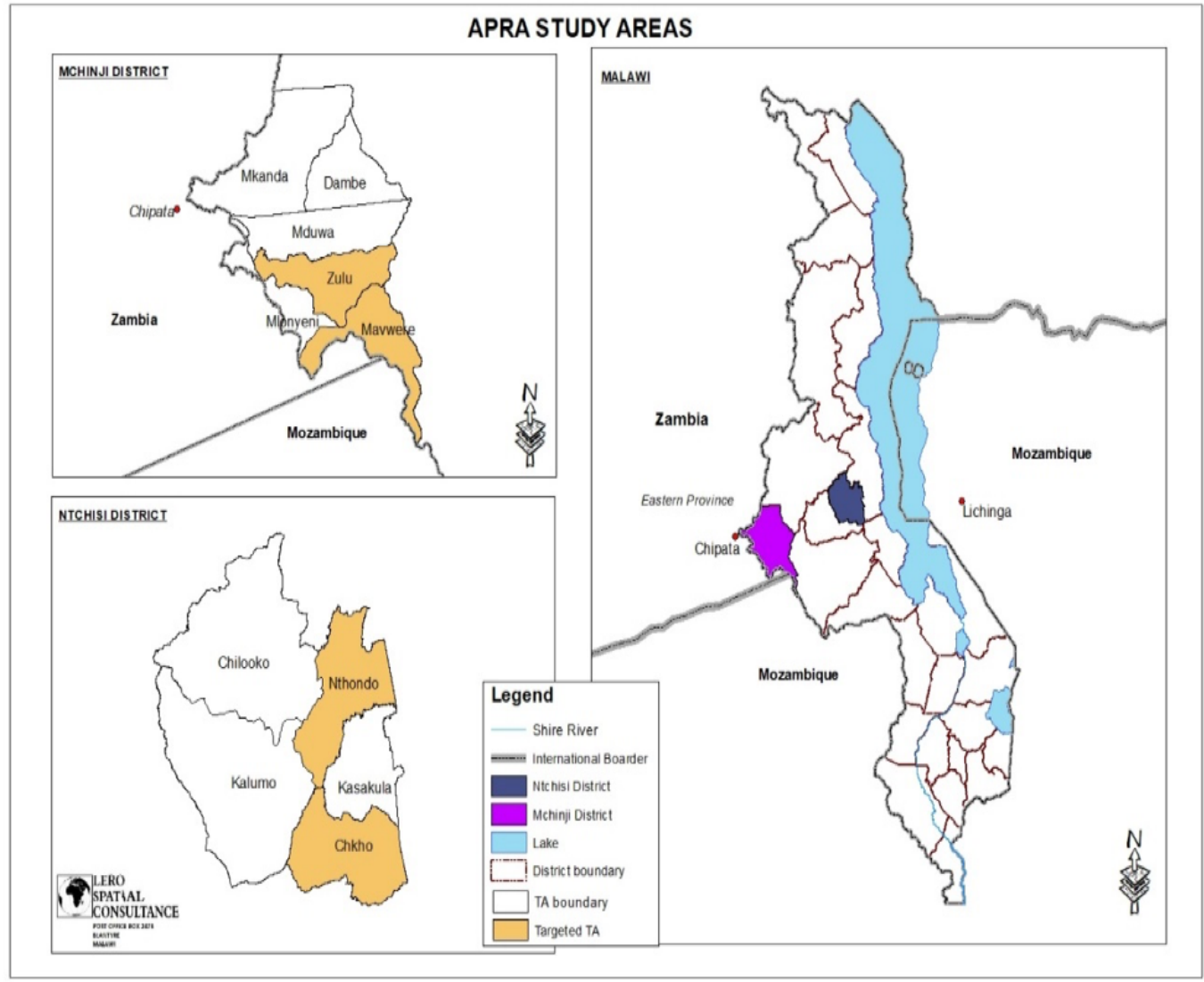

Source: (C) Lero Spatial Consultance, reproduced with permission 
twelfth most vulnerable country to the adverse effects of climate change. Malawi's vulnerability to climate change is exacerbated by increasing poverty among rural areas, increasing population pressures on a limited resource base, land degradation arising from agricultural expansion and the cultivation of marginal lands, and increasing deforestation to meet increasing demands for energy, food, and construction purpose. Farmers' vulnerability to climate change is further compounded by rapidly declining soil fertility, inadequate agricultural policies, and the HIV/AIDS pandemic, which greatly reduces farm labour and drains already meagre financial resources.

The direct effects of the worsening climate change situation on the agriculture sector include significant declines in output and accompanying price spikes for most commodities (CIAT; World Bank, 2018). These effects are exacerbated by the weak adaptive capacity for most communities in rural Malawi. For instance, current small-scale irrigation schemes benefit only 3.5 per cent of rural farming households; practices such as crop diversification are yet to be fully adopted due to biases towards maize and tobacco mono-cropping; and there are limited alternative livelihood options. It is estimated that droughts will increase poverty levels by 1.3 per cent and generate losses on average of 4.5 per cent for maize, the primary food crop.

According to the National Statistics Office (NSO) (2019), the poverty prevalence in both Mchinji and Ntchisi mirrors the national averages. It is estimated that about 46 and 43 per cent of households live below the poverty line in Ntchisi and Mchinji, respectively. Both districts have a mixed tribal heritage of the Chewa and Ngoni. They are further leading agricultural districts in the country attracting migrant labourers from within and other districts across the country. Based on the 2018 Population and Housing Census, Mchinji is more populous than Ntchisi with their populations estimated at 602,305 and 317,069, respectively (NSO, 2019). However, both districts have high population densities estimated at 192 people per km2 and 186 people per km2 for Ntchisi (ibid.).

\subsection{Methodological framework}

We used a mixed-methods approach to data collection and analysis for this study due to the unique nature of the study design - to investigate the processes of change in smallholder farmers' engagement with markets and inherent pathways of commercialisation. This required a dataset that was at least 30 years old as a benchmark to allow us to assess the patterns, configurations, and pathways of change in the livelihoods of the tracked households with sufficient breadth and depth.
In the absence of such a dataset, we opted to use a dataset that was at least 10 years old and which was collected by the SOAS and the NSO as part of the evaluation of the 2006/2007 FISP in Malawi (SOAS et al., 2008). This survey randomly selected respondents from across the country. For the purposes of our study, a sub-dataset for Mchinji and Ntchisi was extracted from the SOAS survey, which we then used for our surveys. The benchmark sub-dataset had 240 households, which we described as 'original households' and their split households as 'branching out' households. Using this sub-dataset, three rounds of fieldwork were carried out as follows: a reconnaissance survey; a quantitative tracker survey; and a qualitative tracker survey.

The districts of Mchinji and Ntchisi were chosen for this study because they are amongst the leading groundnut growing districts in the country. The propensity for commercialisation in these districts is very high because groundnuts are emerging as an alternative cash crop to tobacco which has been in decline since the turn of the 2000s (Chinsinga, 2018; Chinsinga and Matita, 2021). Mchinji was chosen because of the decade-long efforts of the National Association of Smallholder Farmers in Malawi (NASFAM) to promote the commercialisation of groundnuts in the district. Ntchisi was selected for comparative purposes with respect to smallholder farmers' participation in and engagement with markets and commercialisation.

\subsubsection{Reconnaissance survey}

The first step in this study was the reconnaissance survey. A reconnaissance survey provides a snapshot of the situation in an area, often in a historical and contemporary perspective, which is used for planning purposes. Surveys of this nature can provide data on various dimensions of interest sorted, inter alia, by historical period, context, or geographic location (Hamazakaza, undated). A reconnaissance survey was chosen for this study because of its usefulness in forming the basis for more intensive surveys.

The reconnaissance survey was carried out in May 2018 to explore the communities' experiences with commercialisation as well as assess the patterns of change in their livelihoods since the 1980s. Through the survey, we carried out a brief audit of the smallholder farmers' experienceswithagricultural commercialisation within the context of policy developments and changes over the last 30 years, focusing on the enablers and constrainers of agricultural commercialisation. The reconnaissance survey used qualitative techniques of data collection, which included key informant interviews (KIIs) and focus group discussions (FGDs). In both districts, the KIls were carried out with officials at the district level and included NASFAM officials, 
District Trade Officers, District Agribusiness Officers and Agricultural Extension Development Officers. Two FGDs were carried out with farmers in each district, one for farmers who belonged to some form of organisation or association and the other for those not part of any organisation or association. The findings of the reconnaissance survey provided useful insights into the enablers, mediators, and constrainers to smallholder agricultural commercialisation in central Malawi. These findings then fed into the design of the quantitative and qualitative tracker study that targeted both 'original' and 'branching out' households from the original sample of 240 .

\subsubsection{Quantitative survey}

A quantitative survey was conducted during the 2018/2019 growing season. The survey was designed to target all households in the sub-dataset for Mchinji and Ntchisi who were interviewed by SOAS et al. (2008) at baseline, as well as 'branching out' households. Branching out households were only surveyed if they were totally independent from their original households and were approached for the survey if they were living within the borders of Malawi. The rationale for tracing these households was to understand the underlying dynamics and consequent pathways of smallholder agricultural commercialisation. This allowed for comprehensive analysis and deeper understanding of possible pathways of commercialisation and their impact on the different livelihood trajectories.

Table 3.1 shows that we surveyed 210 out of the 240 original households and 302 household members that branched out of the original household. The attrition rate, estimated at 9.6 per cent, among the original households compares very well with similar longitudinal studies elsewhere (Thomas et al., 2012). Through this survey, we modified the SOAS et al. (2008) questionnaire and collected a wider range of information on agricultural practices, input access, household income sources, household engagement with agricultural markets, food security and nutrition among many others.

\subsubsection{Qualitative survey}

The final qualitative survey was undertaken in September 2019 and its design was informed by the findings of the quantitative tracker. Households were classified into five different trajectories: stepping out, stepping up, hanging in, dropping out, and stepping in. This classification was inspired by the Dorward (2009) livelihood framework explained in Matita et al. (2021).

Life histories were chosen as the final qualitative method for this study. According to Ssali et al. (2015), a life history is a qualitative method of data collection where people are asked to document their life over a period in their own words. The life history interviewees were drawn from both original and branching out households. Twelve households were interviewed per livelihood trajectory from the original households, while eight households per trajectory were interviewed from the branching out households. These interviews focused on the role of agriculture and groundnut commercialisation at different stages of their lives. Participants were asked to recall their lived experiences from childhood to old age particularly with reference to how those experiences either facilitated or hindered their families' quest for agricultural commercialisation. These stories were critical to understanding the drivers and dynamics of agricultural commercialisation in rural Malawi.

\subsubsection{Data analysis}

We used both qualitative and quantitative techniques to analyse the data collected for this study. Thematic analysis was used to analyse the results of the reconnaissance survey and life histories. This approach involves closely examining the data to identify common themes, topics, ideas, and patterns of meaning that come up repeatedly (Maguire and Delahunt, 2017; Caulfield, 2020). We interpreted the data using both inductive and deductive approaches although the former dominated. This approach was chosen to juxtapose the participants' accounts and perspectives with our prior knowledge, perspectives, and experiences. ${ }^{1}$

Table 3.1: Sample distribution by year and district

\begin{tabular}{|l|l|l|l|l|}
\hline & $\begin{array}{l}2007 \\
\text { Original households }\end{array}$ & $\begin{array}{l}2018 \\
\text { Tracked original } \\
\text { households }\end{array}$ & $\begin{array}{l}2018 \\
\text { Branching out } \\
\text { households }\end{array}$ & $\begin{array}{l}2018 \\
\text { All households }\end{array}$ \\
\hline Mchini & 102 & 143 & 245 \\
\hline Ntchisi & 120 & 108 & 159 & 267 \\
\hline Total & 240 & 210 & 302 & 512 \\
\hline
\end{tabular}

Source: Authors' own

$1 \quad$ An inductive approach involves allowing the data to determine themes for analysis while the deductive approach involves coming to the data with some preconceived themes expected to be reflected in the data based on theory or existing knowledge (see Caulfield, 2020). 
The quantitative analysis in this study mainly focused on descriptive statistics to draw inferences about smallholder farmers' experiences with agricultural commercialisation. The first main analysis involved classifying the households surveyed into five different livelihood trajectories based on several indicators namely: proportionate change in shares of income from different sources between 2006/07 and 2017/18 season, participation in social safety nets, diversification of income sources, and participation in piece work commonly called 'ganyu'?' In this classification, stepping out implies diversifying away from agriculture; stepping up entails farmers intensifying agricultural production; hanging in means farmers producing barely enough for subsistence; dropping out involves farmers being pushed out of agriculture; and stepping in indicates new people engaging in agriculture having mobilised resources from other livelihood strategies as well as those that never registered agricultural income at baseline (Matita et al., 2021). For the branching out households we used the initial conditions of their original households in the 2006/07 growing season as their baselines. The results of this analysis are presented in Table 2.2, which shows that 13 households stepped out; 64 stepped up; 123 were hanging in; 47 dropped out; and 143 stepped into agriculture.

Table 3.2: Sample distribution by livelihood trajectory

\begin{tabular}{|l|l|l|l|l|l|}
\hline & Stepping out & Stepping up & Hanging in & Dropping out & Stepping in \\
\hline Mchinji & 8 & 20 & 70 & 22 & 53 \\
\hline Ntchisi & 5 & 44 & 53 & 25 & 90 \\
\hline Total & 13 & 64 & 123 & 47 & 143 \\
\hline
\end{tabular}

Source: Authors' own

$2 \quad$ Whiteside (2000) offers a comprehensive definition of ganyu. He defines it as any off own farm work done by rural people on a casual basis. It usually covers a period of days or weeks, remuneration may be in cash or kind (such as food) and is often, but not exclusively, calculated as piece work. Ganyu may be done for relatives, neighbours, smallholders further afield, for estates or even in neighbouring coun tries. The work is often but not exclusively relatively unskilled and agriculturally based. Men, women, and children can do ganyu. 


\section{FINDINGS AND IMPLICATIONS OF THE STUDY}

We present the findings of the study in two major parts. The first part is based on the analysis of the lived experiences of the households that were tracked between the 2007/08 and 2017/18 period. These include both original and branching out households. The second part examines how the lived experiences of these households have either promoted or undermined agricultural commercialisation. These experiences are analysed through several lenses, namely: access to land; social dynamics at household and community levels; production dynamics; access to markets; gender; and social differentiation. The latter two are crosscutting thematic lenses with a particular focus on how they relate to the success and failure of agricultural commercialisation. These findings are situated in the broader context of Malawi's history of agrarian development and transformation, especially since the attainment of independence in July 1964.

\subsection{Livelihood mapping and outcomes}

There are striking differences between original and branching out households as shown in Table 4.1. The results show that the average household size is higher for the original households than for the branching out households. Furthermore, original households have a smaller proportion of $\mathrm{MHH}$ s than branching out households, which may be attributed to death. This should not be surprising because men in Malawi have a lower life expectancy than their female counterparts (NSO, 2019). There were significant changes in the composition of the original households. The age of the household head increased from about 47 years in 2006/07 to 56 years in 2018/19. The proportion of economically active household heads reduced from 98 per cent in 2006/07 to 84 per cent in 2018/19 an inevitable consequence of ageing. The number of

Table 4.1: Characteristics of tracked households

\begin{tabular}{|c|c|c|c|c|c|c|}
\hline \multirow[t]{2}{*}{ Variable } & \multicolumn{2}{|c|}{$\begin{array}{l}\text { Original household } \\
2007\end{array}$} & \multicolumn{2}{|c|}{$\begin{array}{l}\text { Original household } \\
2018\end{array}$} & \multicolumn{2}{|c|}{$\begin{array}{l}\text { Branching out } \\
\text { household }\end{array}$} \\
\hline & Mean & $\begin{array}{l}\text { Std. } \\
\text { Dev. }\end{array}$ & Mean & $\begin{array}{l}\text { Std. } \\
\text { Dev. }\end{array}$ & Mean & $\begin{array}{l}\text { Std. } \\
\text { Dev. }\end{array}$ \\
\hline Household size & 6.28 & 2.54 & $9.32^{\star \star \star}$ & 2.74 & 4.30 & 1.63 \\
\hline$=1$ if head is male & 0.81 & 0.39 & $0.73^{\star \star}$ & 0.45 & 0.89 & 0.31 \\
\hline Age of household head & 47.19 & 16.98 & $55.5^{\star}$ & 13.1 & 29.9 & 8.03 \\
\hline$=1$ if head is economically active & 0.98 & 0.14 & $0.84^{\star \star \star}$ & 0.37 & 0.98 & 0.13 \\
\hline Number of female members below 5 years of age & 0.54 & 0.71 & $0.26^{\star \star \star}$ & 0.53 & 0.55 & 0.62 \\
\hline Number of male members below 5 years of age & 0.44 & 0.62 & $0.25^{\star \star \star}$ & 0.50 & 0.55 & 0.68 \\
\hline Number of female members aged 6-14 years old & 0.72 & 0.88 & 0.73 & 0.87 & 0.40 & 0.74 \\
\hline Number of male members aged 6-14 years old & 0.67 & 0.80 & 0.68 & 0.87 & 0.39 & 0.68 \\
\hline Number of female members aged $15-55$ years old & 1.21 & 0.82 & $1.34^{\star}$ & 1.12 & 1.07 & 0.44 \\
\hline Number of male members aged $15-55$ years old & 1.38 & 1.03 & 1.39 & 1.13 & 1.08 & 0.45 \\
\hline Number of female members older than 55 years & 0.83 & 1.28 & $0.42^{\star \star \star}$ & 0.58 & 0.02 & 0.14 \\
\hline Number of male members older than 55 years & 0.25 & 0.43 & $0.40^{\star \star \star}$ & 0.55 & 0.01 & 0.08 \\
\hline Adult equivalent & 4.90 & 2.09 & $5.07^{\star \star}$ & 2.26 & 3.40 & 1.36 \\
\hline$=1$ if household has male adults only & 0.09 & 0.28 & 0.13 & 0.33 & 0.03 & 0.18 \\
\hline$=1$ if household has female adults only & 0.11 & 0.31 & 0.15 & 0.36 & 0.04 & 0.20 \\
\hline$=1$ if household has both male and female adults & 0.80 & 0.40 & $0.72^{*}$ & 0.45 & 0.92 & 0.27 \\
\hline
\end{tabular}

${ }^{\star} p<0.10,{ }^{* \star} p<0.05,{ }^{\star * \star} p<0.01$

Source: Authors' own 
children under the age of five declined over the two periods, though without significant changes in those aged between six and 14 years. There were marginal increases in the number of female household members aged between 15 and 55 years and no changes among males. Whilst the number of female household members aged more than 56 years decreased - possibly due to deaths - that of males increased likely because of new marriages. The proportion of households with both male and female adults marginally decreased from 80 per cent in 2006/07 to 72 per cent in 2018/19.

It is apparent from this table that branching out households are relatively young, averaging 30 years in age of household heads. These are largely male dominated with about four household members representing on average three adult equivalents. Many of these households are economically active (98 per cent), which is far higher than the estimate for original households. The age-structure composition of branching out households seems to reflect a low dependency burden with one male or female child under the age of five and no members above the age of 55. Most of the branching out households have both male and female adults as members (92 per cent); those with one gender of adult members are below 5 per cent.

Table 4.2 shows the characteristics of original households by livelihood trajectory. Households that are dropping out of agriculture are disproportionately elderly while those stepping out, stepping up and stepping in are predominantly middle-aged. At 62 years, the age of household heads dropping out of agriculture is higher on average than the rest of the livelihood trajectories. This suggests that most of these households are elderly, getting out of the productive age range. This is further reflected in terms of economically active heads in each of these livelihood trajectories. Most households dropping out of agriculture are those that are not economically active and often have either male adults only or female adults only. While the remaining categories have over 90 per cent of economically active household heads, only 76 per cent of those from the dropping out category are economically active. These households are invariably pushed into destitution.

The results do not show any differences in household size among the different livelihood trajectories with an equivalent average of five adult members. It is, nonetheless, important to note that all stepping out households have both female and male adults. These households boast a diversified portfolio of sources of livelihoods, which plays a key role for them to weave their way in and out of agriculture. This makes these households relatively resilient. The proportion of households with both male and female adults is 52 per cent for dropping out households; 74 per cent for stepping up households; 75 per cent for hanging in households; and 74 per cent for stepping in households. Strikingly, the proportion of households with both male and female adults is lower for dropping out households, which may mean that most of these households have either male adults only (20 per cent) or female adults only (20 per cent).

\subsection{Socio-economic characteristics of households}

This section presents the socio-economic performance of both original and branching out households between

Table 4.2: Original household characteristics by livelihood trajectory

\begin{tabular}{|c|c|c|c|c|c|c|c|c|c|c|}
\hline \multirow[t]{2}{*}{ Variable } & \multicolumn{2}{|c|}{$\begin{array}{c}\mathrm{L} 1 \\
(\mathrm{~N}=3)\end{array}$} & \multicolumn{2}{|c|}{$\begin{array}{c}\mathrm{L} 2 \\
(\mathrm{~N}=25)\end{array}$} & \multicolumn{2}{|c|}{$\begin{array}{c}L 3 \\
(N=31\end{array}$} & \multicolumn{2}{|c|}{$\begin{array}{c}L 4 \\
(N=56)\end{array}$} & \multicolumn{2}{|c|}{$\begin{array}{c}L 5 \\
(N=65\end{array}$} \\
\hline & 2007 & 2018 & 2007 & 2018 & 2007 & 2018 & 2007 & 2018 & 2007 & 2018 \\
\hline$=1$ if head is male & 1.00 & 1.00 & 0.72 & 0.56 & 0.83 & 0.74 & 0.89 & 0.82 & 0.77 & 0.69 \\
\hline Age of head in years & 50.00 & 52.67 & 54.68 & 61.56 & 42.83 & 53.81 & 46.64 & 56.29 & 45.73 & 54.71 \\
\hline $\begin{array}{l}=1 \text { if head is } \\
\text { economically active }\end{array}$ & 1.00 & 1.00 & 1.00 & 0.76 & 1.00 & 0.90 & 0.98 & 0.93 & 0.97 & 0.82 \\
\hline Adult equivalent & 4.69 & 6.03 & 5.23 & 4.94 & 5.10 & 5.25 & 4.95 & 4.88 & 5.29 & 5.93 \\
\hline Household size & 7.00 & 10.00 & 6.80 & 9.52 & 6.53 & 9.61 & 6.11 & 9.09 & 6.75 & 9.97 \\
\hline $\begin{array}{l}=1 \text { if household has } \\
\text { male adults only }\end{array}$ & 0.00 & 0.00 & 0.12 & 0.20 & 0.03 & 0.13 & 0.13 & 0.11 & 0.03 & 0.09 \\
\hline $\begin{array}{l}=1 \text { if household has } \\
\text { female adults only }\end{array}$ & 0.00 & 0.00 & 0.28 & 0.20 & 0.10 & 0.13 & 0.02 & 0.14 & 0.15 & 0.17 \\
\hline $\begin{array}{l}=1 \text { if household has } \\
\text { both male and female } \\
\text { adults }\end{array}$ & 1.00 & 1.00 & 0.60 & 0.52 & 0.87 & 0.74 & 0.85 & 0.75 & 0.82 & 0.74 \\
\hline
\end{tabular}

Notes: $\mathrm{L} 1$ = stepping out; $\mathrm{L} 2$ = dropping out; $\mathrm{L} 3=$ stepping up; $\mathrm{L} 4=$ hanging in; and $\mathrm{L} 5=$ stepping in. 
2007/08 and 2017/18 period. According to Table 4.3, the original households demonstrate varied patterns of asset accumulation across the different livelihood trajectories. The results indicate that households' value of assets increased across all the livelihood trajectories with remarkable increase for households that are stepping out, stepping up, and stepping in agriculture. Households that are dropping out and hanging in agriculture experienced marginal increases in the value of their assets. The number of livestock units marginally increased across the livelihood trajectories with smaller increases for households that are dropping out, stepping up, and stepping in agriculture. There was a decrease in the number of livestock units for households in stepping out and hanging in livelihood trajectories. The proportion of households that purchase commercial fertiliser increased across the livelihood trajectories, except for stepping out households. This is not surprising because these households have scaled down their involvement in agriculture. Access to subsidised inputs decreased over time and across all trajectories. This could be attributed to fluctuations in the number of FISP beneficiaries between 1.3 million farmers to 900,000 farmers in recent years (Nkhoma, 2018).

The results show that land ownership progressively decreased over time and across trajectories apart from the stepping in households. These households experienced increases in land at their disposal due to purchasing or renting land to boost agricultural production. The amount of land cultivated under irrigation increased over time and across the trajectories, but the proportion of households that cultivate under irrigation decreased over the two periods and across the trajectories. In contrast, the amount of land cultivated under rain-fed irrigation declined overall.

In addition, the results indicate that both the amount of land rented out and rented in increased marginally over time and across the trajectories, except for those stepping out of agriculture households. The proportion of households that hire in agricultural labour also increased marginally over time and across the trajectories. The amount of land available to each household is diminishing due to original households

Table 4.3: Socio-economic characteristics of original households by livelihood trajectory

\begin{tabular}{|c|c|c|c|c|c|c|c|c|c|c|}
\hline \multirow[t]{3}{*}{ Variable } & \multicolumn{2}{|c|}{ All households } & \multicolumn{2}{|c|}{ L1 } & \multicolumn{2}{|c|}{ L2 } & \multicolumn{2}{|c|}{ L3 } & \multicolumn{2}{|c|}{ L4 } \\
\hline & \multicolumn{2}{|c|}{$(\mathrm{N}=173)$} & \multicolumn{2}{|c|}{$(\mathrm{N}=3)$} & \multicolumn{2}{|c|}{$(\mathrm{N}=25)$} & \multicolumn{2}{|c|}{$(\mathrm{N}=30)$} & \multicolumn{2}{|c|}{$(\mathrm{N}=55)$} \\
\hline & 2007 & 2018 & 2007 & 2018 & 2007 & 2018 & 2007 & 2018 & 2007 & 2018 \\
\hline Value of assets in US\$ & 158.40 & 307.27 & 46.5 & 289.44 & 26.05 & 40.37 & 72.49 & 302.06 & 149.01 & 139.69 \\
\hline Total livestock units & 0.82 & 0.85 & 2.87 & 1.02 & 0.10 & 0.22 & 0.79 & 1.01 & 0.96 & 0.91 \\
\hline Land owned (ha) & 2.11 & 2.00 & 7.00 & 1.13 & 1.58 & 1.11 & 1.83 & 1.18 & 2.67 & 2.24 \\
\hline $\begin{array}{l}=1 \text { if purchase } \\
\text { commercial fertiliser }\end{array}$ & 0.36 & 0.63 & 0.67 & 0.33 & 0.20 & 0.44 & 0.43 & 0.57 & 0.31 & 0.71 \\
\hline $\begin{array}{l}=1 \text { if receive subsidy } \\
\text { coupon }\end{array}$ & 0.53 & 0.08 & 0.67 & 0.00 & 0.48 & 0.00 & 0.53 & 0.07 & 0.65 & 0.09 \\
\hline $\begin{array}{l}=1 \text { if hire agricultural } \\
\text { labour }\end{array}$ & 0.16 & 0.27 & 0.00 & 0.33 & 0.04 & 0.24 & 0.17 & 0.23 & 0.25 & 0.36 \\
\hline $\begin{array}{l}\text { Amount of land } \\
\text { cultivated under } \\
\text { irrigation (ha) }\end{array}$ & 0.26 & 0.61 & 0.47 & 1.60 & 0.27 & 0.36 & 0.21 & 0.30 & 0.40 & 0.69 \\
\hline $\begin{array}{l}\text { Amount of land } \\
\text { cultivated under rain- } \\
\text { fed (ha) }\end{array}$ & 1.85 & 1.86 & 6.53 & 1.60 & 1.31 & 1.10 & 1.62 & 1.28 & 2.27 & 2.21 \\
\hline $\begin{array}{l}=1 \text { if cultivate under } \\
\text { irrigation }\end{array}$ & 0.64 & 0.33 & 1.00 & 0.67 & 0.68 & 0.32 & 0.63 & 0.30 & 0.82 & 0.33 \\
\hline $\begin{array}{l}\text { Amount of land } \\
\text { rented-out (ha) }\end{array}$ & 0.06 & 0.12 & 0.00 & 0.00 & 0.03 & 0.05 & 0.00 & 0.04 & 0.13 & 0.28 \\
\hline $\begin{array}{l}\text { Amount of land } \\
\text { rented-in (ha) }\end{array}$ & 0.08 & 0.12 & 0.00 & 0.00 & 0.02 & 0.06 & 0.03 & 0.12 & 0.11 & 0.10 \\
\hline $\begin{array}{l}=1 \text { if had adequate } \\
\text { food last month }\end{array}$ & 0.69 & 0.35 & 1.00 & 0.33 & 0.40 & 0.24 & 0.63 & 0.30 & 0.76 & 0.36 \\
\hline $\begin{array}{l}\text { Commercialisation } \\
\text { index }\end{array}$ & 23.36 & 53.53 & 40.36 & 0.00 & 18.05 & 23.83 & 30.46 & 57.68 & 28.18 & 55.01 \\
\hline$=1$ if access any credit & 0.14 & 0.10 & 0.00 & 0.00 & 0.24 & 0.08 & 0.20 & 0.13 & 0.15 & 0.11 \\
\hline
\end{tabular}

Notes: $L 1$ = stepping out; $L 2$ = dropping out; $L 3=$ stepping up; $L 4=$ hanging in; and $L 5=$ stepping in.

Source: Authors' own 
further dividing their land as inheritance for branching out households with possibilities of renting in land for those who can afford it.

The results in Table 4.4 demonstrate the worsening food security situation in rural Malawi, showing an increase in the proportion of households that did not have adequate food a month before the survey was carried out. This is likely related to the timing of the survey. The 2018/19 survey was conducted in October, which is part of the lean season while the 2007/08 survey was carried out in May during the harvest period. As expected, the results showed deteriorating food security because during October most households have lean food stocks or experience food stocks-outs. In addition, the food security situation deteriorated across all livelihood trajectories, which highlights the increasing fragility of livelihoods in rural Malawi. On the other hand, the proportion of households' marketing their produce as measured by the household commercialisation index $(\mathrm{HCl})$ increased over time and across trajectories. With the liberalisation of crop marketing, strides have been made in integrating households into markets, though these are often informal, characterised by middlemen that offer low prices relative to government set prices. The proportion of households with access to some form of credit marginally decreased over this period and across the trajectories, except for stepping in households.

The results in Table 4.4 also show that branching out households are generally better off than their original households except in the hanging in and stepping in category. Stepping out, dropping out, and stepping up households have a higher value of assets than their original households in 2007 while hanging in and stepping in households have a lower value of assets than their original households. Branching out households own less livestock units and amount of land compared to their original households across all livelihood trajectories. The proportion of branching out households that purchase commercial fertilisers is higher for stepping out and stepping up households and lower for dropping out, hanging in, and stepping in households than their original households. The proportion of households with access to subsidised inputs is higher for dropping out and hanging in branching out households and lower for stepping in branching out households compared to their original households. Similar to original households, none of the stepping out branching out households received subsidy coupons under the auspices of FISP.

In addition, the results indicate that stepping up and stepping in branching out households rent out more land while dropping out and hanging in branching out households rent out less land than their corresponding original households at baseline. Conversely, stepping out, stepping up, and hanging in branching out households rent in marginally more land whereas dropping out branching out households rent in marginally less land than their corresponding original households. The proportion of households that hire in agricultural labour is higher for dropping out households - likely due to a lack of physical labour as

Table 4.4: Socio-economic characteristics of branching out households by livelihood trajectory compared to their original households.

\begin{tabular}{|c|c|c|c|c|c|c|c|c|}
\hline \multirow[t]{2}{*}{ Variable } & \multicolumn{2}{|c|}{ L1 } & \multicolumn{2}{|c|}{ L2 } & \multicolumn{2}{|c|}{ L3 } & \multicolumn{2}{|c|}{ L4 } \\
\hline & 2007 & 2018 & 2007 & 2018 & 2007 & 2018 & 2007 & 2018 \\
\hline Value of assets in US\$ & 46.52 & 245.92 & 26.05 & 121.62 & 72.49 & 180.59 & 149.01 & 129.87 \\
\hline Total livestock units & 1.02 & 0.63 & 0.22 & 0.16 & 0.98 & 0.27 & 0.89 & 0.30 \\
\hline Land owned (ha) & 3.20 & 1.50 & 1.46 & 0.82 & 1.54 & 1.15 & 2.85 & 0.92 \\
\hline $\begin{array}{l}=1 \text { if purchase commercial } \\
\text { fertiliser }\end{array}$ & 0.33 & 0.50 & 0.44 & 0.41 & 0.55 & 0.58 & 0.70 & 0.63 \\
\hline$=1$ if receive subsidy coupon & 0.00 & 0.00 & 0.00 & 0.09 & 0.06 & 0.06 & 0.09 & 0.10 \\
\hline$=1$ if hire agricultural labour & 0.33 & 0.30 & 0.24 & 0.27 & 0.23 & 0.12 & 0.36 & 0.28 \\
\hline Amount of land rented-out (ha) & 0.00 & 0.00 & 0.05 & 0.03 & 0.04 & 0.06 & 0.28 & 0.01 \\
\hline Amount of land rented-in (ha) & 0.00 & 0.14 & 0.06 & 0.05 & 0.13 & 0.14 & 0.10 & 0.32 \\
\hline $\begin{array}{l}=1 \text { if had adequate food last } \\
\text { month }\end{array}$ & 0.33 & 0.50 & 0.24 & 0.45 & 0.32 & 0.30 & 0.36 & 0.43 \\
\hline$=1$ if access any credit & 0.00 & 37.17 & 0.08 & 34.43 & 0.13 & 58.87 & 0.11 & 53.55 \\
\hline Commercialisation index & 0.55 & 0.59 & 0.24 & 0.39 & 0.59 & 0.77 & 0.55 & 0.69 \\
\hline $\mathrm{N}$ & 3 & 10 & 25 & 22 & 31 & 33 & 56 & 67 \\
\hline
\end{tabular}

Notes: $L 1$ = stepping out; $L 2=$ dropping out; $L 3=$ stepping up; $L 4=$ hanging in; and $L 5=$ stepping in. Source: Authors' own 
they age - and stepping in branching out households, and lower for stepping out, stepping up, and hanging in branching out households than their corresponding original households.

The results further show that branching out households appear more food secure than their original households except for stepping up households. The proportion of households that had adequate food a month before the survey is higher for branching out households than their corresponding original households at baseline, except for stepping up branching out households. This suggests that the food security situation for most branching out households is better than the food security situation for their corresponding original households. The proportion of branching out households with access to some form of credit is higher across the trajectories than that recorded for original households. Similarly, branching out households engage more with output markets than their corresponding original households at across the trajectories.

\subsection{Sources of income for households}

This section examines the composition of income sources for both original and branching out households. Table 4.5 presents the components of these sources for original households.
The results indicate that the contribution of crop sales to household income increased over the ten-year period between 2008 and 2018. Across the trajectories, crop sales' contribution increased for stepping in households and decreased for dropping out and hanging in households. The proportion of income from livestock sales also increased between 2008 and 2018. This income, however, decreased across stepping out, dropping out, stepping up, and hanging in households and increased for stepping in households. The contribution of livestock products to household income marginally increased over time with stepping in households getting a greater contribution and stepping up households receiving a lower contribution than at baseline. Overall, the contribution of business enterprises to household income decreased between the two periods, increasing only for stepping out and decreasing for the rest of the livelihood trajectories. Similarly, the contribution of ganyu to household income decreased between the two periods. Stepping out households no longer receive income from ganyu while the proportion of reliance on ganyu decreased for dropping out, stepping up, and stepping in households. Conversely, the importance of ganyu income increased for hanging in households, which is unsurprising given that the livelihoods of households in this category border on destitution.

Table 4.5: Income sources for original households (proportion)

\begin{tabular}{|c|c|c|c|c|c|c|c|c|c|c|c|c|}
\hline \multirow[t]{2}{*}{ Variable } & \multicolumn{2}{|c|}{$\begin{array}{c}\text { All } \\
\text { households }\end{array}$} & \multicolumn{2}{|c|}{ L1 } & \multicolumn{2}{|c|}{ L2 } & \multicolumn{2}{|c|}{ L3 } & \multicolumn{2}{|c|}{ L4 } & \multicolumn{2}{|c|}{ L5 } \\
\hline & 2007 & 2018 & 2007 & 2018 & 2007 & 2018 & 2007 & 2018 & 2007 & 2018 & 2007 & 2018 \\
\hline Crop sales & 0.48 & 0.90 & 1.00 & 0.00 & 0.48 & 0.44 & 1.00 & 1.00 & 1.00 & 0.98 & 0.00 & 1.00 \\
\hline Livestock sales & 0.24 & 0.29 & 0.33 & 0.00 & 0.24 & 0.16 & 0.47 & 0.26 & 0.49 & 0.30 & 0.00 & 0.35 \\
\hline Livestock products & 0.02 & 0.07 & 0.00 & 0.00 & 0.00 & 0.00 & 0.07 & 0.06 & 0.02 & 0.02 & 0.00 & 0.15 \\
\hline Business enterprise & 0.42 & 0.17 & 0.00 & 0.67 & 0.48 & 0.08 & 0.67 & 0.29 & 0.16 & 0.16 & 0.42 & 0.14 \\
\hline Any ganyu & 0.47 & 0.40 & 0.67 & 0.00 & 0.68 & 0.40 & 0.70 & 0.55 & 0.24 & 0.36 & 0.50 & 0.38 \\
\hline $\begin{array}{l}\text { Number of } \\
\text { observations }\end{array}$ & 239 & 180 & 3 & 3 & 22 & 25 & 30 & 31 & 55 & 56 & 60 & 65 \\
\hline
\end{tabular}

Notes: $\mathrm{L} 1$ = stepping out; $\mathrm{L} 2=$ dropping out; $\mathrm{L} 3=$ stepping up; $\mathrm{L} 4=$ hanging in; and $\mathrm{L} 5=$ stepping in.

Source: Authors' own

Table 4.6: Income sources for branching out households in 2018 (proportion)

\begin{tabular}{|l|l|l|l|l|l|l|}
\hline Income sources & All HH & LH 1 & LH 2 & LH 3 & LH 4 & LH 5 \\
\hline Crop sales & 0.78 & 0.40 & 0.41 & 0.88 & 0.87 & 0.82 \\
\hline Livestock sales & 0.21 & 0.00 & 0.09 & 0.24 & 0.21 & 0.27 \\
\hline Livestock products & 0.01 & 0.00 & 0.00 & 0.00 & 0.03 & 0.01 \\
\hline Business enterprise & 0.33 & 0.80 & 0.23 & 0.24 & 0.34 & 0.32 \\
\hline Any ganyu & 0.57 & 0.50 & 0.68 & 0.70 & 0.55 & 0.50 \\
\hline Number of observations & $\mathbf{2 1 0}$ & $\mathbf{1 0}$ & $\mathbf{2 2}$ & $\mathbf{3 3}$ & $\mathbf{6 7}$ & $\mathbf{7 8}$ \\
\hline
\end{tabular}

Notes: $\mathrm{L} 1$ = stepping out; $\mathrm{L} 2$ =dropping out; $\mathrm{L} 3$ = stepping up; $\mathrm{L} 4$ = hanging in; and $\mathrm{L} 5$ = stepping in.

Source: Authors' own 
Broadly similar patterns were observed in branching out households as presented in Table 4.6. The results show that branching out households generally engage more with markets than their original households. Both original and branching out households have a higher commercialisation index, but the returns to farmers are not high enough to drive commercialisation sustainably.

The results indicate that dropping out households mostly get their income from ganyu work while stepping up branching out households get most of their income from crop sales (88 per cent), and ganyu (70 per cent). In addition, hanging in branching out households receive most of their income from crop sales (87 per cent), and ganyu (55 per cent) whereas stepping in branching out households get most of their income from crop sales (82 per cent) and ganyu (50 per cent). Stepping out households rely more on business enterprise as their main source of income; dropping out on ganyu as their main source of income; while stepping out, stepping in and hanging in rely more on crop sales. This is line with the expectation that those that step out should make more investments outside agriculture while those that step in enhance their investments within agriculture. However, ganyu seems to be a secondary source of income for those stepping up, stepping in and hanging in.

While inequalities remain deeply entrenched in rural Malawi, there have been some notable changes over the two periods. In 2007, the top 20 per cent of the population were getting 80 per cent of all income while the bottom 20 per cent received only 0.2 percent of all income. There seemed to be even distribution in terms of households in different income quintiles. In 2018, the top 20 per cent of the population received 87 per cent of all income whilst the bottom 20 per cent obtained 0.4 per cent of all income. Furthermore, inequalities defined in terms of Gini coefficients remained pervasive. The Gini coefficient of income per adult equivalent in 2007 among original households was 0.77 compared to 0.87 estimated in 2018 representing increasing inequalities in the communities. The Gini coefficient for branching out households was estimated at 0.80 in 2018. The income inequalities were more pronounced in Mchinji than Ntchisi district with Gini coefficients estimated at 0.89 and 0.71 among the original households, respectively in 2018 .

\subsection{Production dynamics and agricultural commercialisation}

There have been several changes in the overall operative environment for the agricultural sector since the baseline was conducted in the 2006/07 growing season. During this period, for instance, tobacco continued to lose its prominence as the country's leading cash crop due to a combination of factors including the fierce anti-smoking lobby mounted within the context of the World Health Organisation Framework Convention on Tobacco Control (Prowse and Grassin, 2020). The groundnut value chain has continued to recover, particularly in terms of production due to various NGO and donor initiatives, government policies and programmes, and the continued decline of tobacco. Through the National Export Strategy, there have been concerted efforts to promote legumes, particularly soybeans and groundnuts, as potential alternative cash crops to tobacco. Several policies have been adopted including the National Agricultural Policy (NAP), which provides an overarching framework for harnessing transformative agricultural development in the country. The adoption of the NAP has witnessed renewed efforts to fully operationalise the pluralistic demand-driven extension policy that was inaugurated at the turn of the new millennium. The policy promotes the development of pluralistic and demand driven agricultural extension services by involving stakeholders and promoting participatory planning and implementation of agricultural programmes (GoM, 2000).

The results in Table 4.9 indicate that the proportions of households that cultivate certain crops have changed over the years. For instance, 49 per cent of the households cultivated groundnuts, 27 per cent soybeans, 20 per cent tobacco, and 18 per cent maize in 2007, while 24 per cent of the households cultivated groundnuts, 59 per cent soybeans, 11 per cent tobacco, 79 per cent maize, 18 per cent beans, and 15 per cent sweet potatoes in 2018. Consistent with national trends seen based on integrated surveys, households have shifted away from tobacco, which is grown principally as a cash crop towards more food crops, which households also sell to earn an income. The in-depth interviews with some of these households revealed that a decision to cultivate groundnuts or soybeans is largely informed by the market prices for these crops and the diminishing profits from tobacco due to a decrease in quality and yields, and increased transport, transportation, and marketing costs. Households cultivate more groundnuts and less soybeans in the next agricultural season if the price of groundnuts is better than that of soybeans in the current agricultural season or vice versa. The provision of improved legume seed under FISP and availability of markets might be contributing factors to increased production of legumes while a reduction in the proportion of households that cultivate tobacco might be attributed to lower prices offered at auction floors and increased rejection of non-contract tobacco producers. 
The results show that there has been a great improvement in farmers' access to extension services despite most of them consistently complaining about the near absence of, or poor quality of extension services. While only 22 per cent of original households reported receiving any extension service in 2007, 83 per cent (85 per cent for branching out households) reported doing so in 2018. This could possibly be attributed to the positive impact of the pluralistic extension policy of 2000 that allows private sector entities and NGOs to participate in the provision of agricultural extension services. The results further show that on average, households received information on nine good agricultural practices in 2018. The top messages reported by about 50 per cent of branching out households included those on crop rotation, timely planting, weeding and fertiliser application and food and nutrition practices. For the original households, the top messages in 2018 were on timely planting, weeding and fertiliser application, application of inorganic fertilisers and agroforestry.

The proportion of households with access to subsidised fertilisers decreased from 52 per cent in 2007 to 6 per cent in 2018. Conversely, the proportion of households that purchase commercial fertiliser increased from 35 per cent in 2007 to 59 per cent in 2018. A move towards more commercial fertiliser is a positive step to increase agricultural output and level of household engagement with input markets given that access to subsidised fertilisers is unsustainable. These are significant differences, but challenges remain to achieve higher productivity especially among the poorest households. Over the years soils have also degraded to the extent that cropping without soil fertility management practices does not give optimal yields ${ }^{3}$.

The proportion of households with uncultivated portions of land declined from 29 per cent in 2007 to 21 per cent in 2018. There are two main factors that have contributed to this development. Original households have passed on more land to branching out households coupled with increasing pressure to provide for growing families. The practice of renting in land has intensified, especially by people outside the local communities. In estimating the land that households have cultivated, they included land that they had not directly cultivated, but they had rented out to others. As the pressure for land acquisition by emerging medium-scale farmers mount, there will be no fallow land in these areas (Chinsinga and Matita, 2021).

\subsection{The land question in rural Malawi}

Land is the single most important productive asset for each household in rural Malawi. Almost all households indicated having at least some piece of land, which they used for cultivation of crops. In several FGDs and life histories, land was described as 'life so much that without land one is as good as dead'. ${ }^{4}$ In the wealth ranking exercises, communities described the poorest

Table 4.7: Production dynamics for original households

\begin{tabular}{|c|c|c|}
\hline \multirow{2}{*}{ Variable } & 2007 & LH \\
\hline & $(\mathrm{N}=239)$ & 2018 \\
\hline \multicolumn{3}{|l|}{ Crops cultivated } \\
\hline$=1$ if cultivate groundnuts & 49 & 24 \\
\hline$=1$ if cultivate soybeans & 27 & 59 \\
\hline$=1$ if cultivate tobacco & 20 & 11 \\
\hline$=1$ if cultivate maize & 18 & 79 \\
\hline$=1$ if cultivate beans & 5 & 18 \\
\hline$=1$ if cultivate sweet potatoes & 7 & 15 \\
\hline \multicolumn{3}{|l|}{ Access to fertilisers } \\
\hline$=1$ if access subsidised fertilisers & 52 & 6 \\
\hline$=1$ if access commercial fertilisers & 35 & 59 \\
\hline$=1$ if left some land uncultivated/fallow & 29 & 21 \\
\hline Accessed any extension services & 22 & 83 \\
\hline
\end{tabular}

Source: Authors' own

3 Life history interview with D110 at Tsekaphata Village, TA Chinkho in Ntchsi, November 2019; D64 at Malison Village, TA Simphasi in Mchinji, September 2019 
as those who do not have access to land either because they sold it off or perpetually rent it out. They survive on either ganyu or piece work for which they are paid either in cash or kind (Chinsinga, 2004).

The findings of this study show that land access in rural Malawi is still predominantly through traditional means (Kishindo, 2004; Peters, 2004; Takane, 2008). The customary land tenure and inheritance laws stipulate that every individual, by virtue of membership in a community, is entitled to access a piece of land while outsiders such as migrants may be allocated a piece of land, provided that vacant land is available and the recipients respect community tradition and customs. Once acquired, land rights can be handed over to heirs on a quasi-permanent basis. When a land holder and his or her kin members all die or move out of the village the land must be returned to the community for reallocation to other community members. Under this arrangement, the notion of selling land therefore does not exist (Mkandawire, 1984) yet land markets for customary land have existed for generations. Increasingly, community members are augmenting their land through renting on an annual basis from those who either have surplus land or cannot simply manage to cultivate it. Both buying and renting of land are driven by different forces but appear to benefit disproportionately those who are endowed with monetary resources (Takane, 2008; Peters, 2004).

The results of the study also demonstrated increasing land scarcity in rural Malawi which may be attributed to rapid proliferation of estates between the 1970s and 2000s and exponential population growth estimated at 3.2 per cent annually (Kishindo, 1997; Whiteside, 2000; Mangani et al., 2020). It is estimated that the number of estates grew from 229 in 1970 to 22,000 in 2000. Dickermand and Bloch (1991), for example, established that in Mchinji 45 per cent of arable land was held by estates and the average customary land holding size dropped from 2 ha in 1980/81 to 1.6ha in 1987. Life history interviews consistently echoed the problem of increasing land scarcity. This was principally attributed to increasing land fragmentation arising out of inheritance particularly for larger families. One of the respondents, for example, indicated that 'I have inherited some land from my parents, but it is not as big as I would have liked... it less than a hectare... it is all because there were too many children in our family'5. The problem is even more pronounced in polygamous families. While traditionally, inheritance prioritises children from senior wives, the practice is different. From this study, it greatly depends on the relationships between the parent and his or her benefactors as evidenced by one respondents' life history account:

Our family has grappled with serious shortage of land. My siblings and I do not have adequate land inherited from our parents. It was not simply possible because my mother's side did not have adequate land; we relied on my father's side. The challenge is that my grandfather had several wives hence many children amongst whom to share the land. My father has been sharing it to us the little piece of land he inherited from my polygamous grandfather. (Life history interview with D90 at Nkone Village, T/A Chilowoko, Ntchisi District, 8 November 2019)

In addition, the land market in rural Malawi, in terms of both renting and outright sales, has been deepened and broadened following the emergence of weekend farmers (Answeeuw et al., 2016; Chinsinga, 2018; Chinsinga and Matita, 2021). Most of the stepping in farmers are urban-based professionals, entrepreneurs, and civil servants who are moving into agriculture largely as a post-retirement occupation. Through the 'vernacular' land markets, the emerging farmers are buying land mostly from smallholder farmers that are either 'hanging in' or dropping out of agriculture. These land sales are driven by distress or desperation to survive and are an indicator of greater and worsening impoverishment of smallholder farmers in rural Malawi (Dickermand and Bloch, 1991; Muyanga et al., 2020). These districts are therefore experiencing massive proletarianization, whereby displaced villagers rely almost exclusively on their labour as a means of livelihood, working on land that they previously owned. Most of these farmers have become what Bernstein (1982) calls petty commodity producers, who individually cultivate pieces of land that are too small to commercialise their agricultural enterprises successfully and profitably.

The land rental market is particularly thriving in Mchinji. Several life history respondents indicated that the land rental market has been given a new lease of life with the re-emergence of groundnuts as a lucrative cash crop and a potential alternative to tobacco. In both districts, Burundians, who operate the Mgona informal groundnut export market, either commission community members to grow groundnuts which they must sell to them or cultivate the land themselves. This has pushed up the demand for land for renting purposes. The annual rent fee per acre fluctuated 
between MK20,000 and MK50,0006 . In addition, there is also an increasing number of households who are renting in land 'as a means to expand their hectarage for food production to guarantee food security'. These developments are taking place when the country's land legislative framework is yet to be settled to provide definitive guidance on land matters.

Finally, several life history respondents reported being involved in protracted land disputes. Land disputes are often long drawn out partly because the land legislative framework is in a state of flux. These cases should be ideally adjudicated on by traditional leadership structures, but increasingly community members are losing trust in them. Most of the respondents indicated that 'with the allure of money from better off parties to land disputes, traditional leaders rarely dispense justice impartially in land matters. ${ }^{8}$

While there are various forms of land disputes, the dominant disputes involve paternal relations grabbing land from either children of the deceased or their widows ${ }^{9}$. In most cases, the children and wives just give up and descend into destitution. These cases are reportedly rampant in cases of virilocal residence. One life history respondent stated:

We were living at my father's home village, cultivating land from his parent's side. Our problems started immediately after our father died. My mother was ordered to leave. We moved out of my father's land. We were saved by a traditional leader from the nearby village who acted as a well- wisher... he allocated us a new piece of land. (Life history interview with D120 at Filipo Village, T/A Nthondo, Ntchisi District, 28 October 2019)

In cases where victims of land grabbing have fought to reclaim the land, the consequences have often been quite damaging to their livelihoods. From life history interviews, these cases take on average three to five years to get fully resolved, are costly and not always in favour of the complainants. Most complainants prefer to take land matters to the district level court system rather than to traditional leaders.
Due to the protracted nature of land cases and the location of the court's litigants are often forced to sell some of their productive assets such as livestock and household effects to fund court appearances. The following sentiments from a life history interview illustrate these challenges:

When my father died, his relatives started cultivating his land at the expense of my mother and us children. My mother sold the livestock we had to raise money to facilitate her movements to the district court where she had sued her inlaws for grabbing our land. It was a long court process, which required frequent attendance. We lost everything that we had including some durable household assets to fund the land litigation process. It was a double jeopardy for us: the case just died a natural death. (Life history interview with D1 at Mchaka GVH, T/A Mabvere, Mchinji District, 25 September 2019)

Overall, the findings of the study reveal that there are several processes at play vis-à-vis the land question in rural Malawi. These processes are mixed, complex, and non-unidirectional. This reinforces Berry's (1993) observation that land in rural Africa is subject to multiple controls and to a dynamic litigation and struggle that fosters investment in social relations maintaining fluidity and negotiability. The commoditisation of land through the vernacular markets, particularly in the context of the land legislative impasse co-exists with the customary view of land as a collective community or lineage resource which is not sold (Mkandawire, 2004; Takane, 2008).

\subsection{Social dynamics and agricultural commercialisation}

The examination of the influence of social dynamics on agricultural commercialisation focused on the following broad areas: 1) gender, kinship, and agricultural commercialisation; 2) class, asset accumulation and agricultural commercialisation and 3) social networks, migration, shocks, and agricultural commercialisation.

6 About US\$25 to US\$62at US\$1 = MK810 according to the Reserve Bank of Malawi, 27th July 2021 available at https://www.rbm.mw/statistics/MajorRates/

7 Life history interview with D10 at Kachepa Village, T/A Mduwa, Mchinji District, 6 October 2019

8 Life history interview with D80 at Chisusu Village, T/A Kapichila, Kasungu District, 12 November 2019

$9 \quad$ The land grabbers are predominantly in-laws, uncles and brothers to their late husbands or fathers. Due to these land grabs, most widows indicated that death of their husbands was the most devastating shock that they have experienced. The deaths stand out as turning point for the worse in their livelihood status. The deaths triggered downward spirals in livelihood status that they have not been able to reverse. These are compounded by the responsibility shoulder school fees, medical bills and productivity decline following little or limited access to land and in the context of worsening effects of climate change. 
These categories are not mutually exclusive; there are considerable overlaps. They have been delineated as such largely for conceptual and analytical purposes.

\subsubsection{Gender, kinship, and agricultural commercialisation}

We focused on two distinct scenarios to examine the influence of gender and kinship on agricultural commercialisation. In the first scenario, we compared the performance of $\mathrm{MHHs}$ and $\mathrm{FHHs}$ regarding agricultural commercialisation and examined the drivers behind their diverse experiences, including the role of their engagement in economic activities. In the second scenario, we concentrated on the intrahousehold social dynamics between men and women and the rest of the household members. We examined issues such as decision-making processes; access, control, and ownership of productive resources; and the distribution of benefits from both on-farm and offfarm enterprises.

The results of the study show that most farmers in rural Malawi are struggling. They are grappling with a worsening productivity crisis and are unable to grow enough crops to feed themselves throughout the year (Whiteside, 2000; da Corta et al., 2018; Mangani et al., 2020). Most of the farmers are simply 'hanging in' in agriculture. A limited number of farmers are 'stepping in', 'stepping up' or 'stepping out' of agriculture. The $\mathrm{HCl}$ shows significant statistical differences in the degree or level of commercialisation between $\mathrm{MHHs}$ and $\mathrm{FHHs}$. The $\mathrm{HCl}$ shows that $\mathrm{MHH}$ are more commercialised than $\mathrm{FHHs}$ with an average of 0.58 for $\mathrm{MHH}$ and 0.50 for $\mathrm{FHHs}$ (Matita, et al., 2021).

This is not a surprising finding. Djurfeldt et al. (2018) obtained similar results in Malawi. They attributed these findings to differential access to markets by men and women; challenges in mobility to get agricultural produce to the market including the associated transaction costs; and women's involvement in commercial agriculture does not excuse them from their housework and childcare responsibilities. They further observed that further observed that while both $\mathrm{MHH}$ and $\mathrm{FHH}$ diversified their livelihood sources, overall, $\mathrm{MHH}$ s were more likely to receive income from agriculture than $\mathrm{FHHs}$. The latter tend to dominate non-farm income sources such as agricultural wages and ganyu. Studies on ganyu characterise it predominantly as a coping mechanism during periods of acute food shortages and households engage in it as a survival technique of the last resort (Whiteside, 2000; Chinsinga, 2004). It is thus the most important coping strategy for very poor households in the crucial hungry period between food stores running out and the next harvest. Even though women dominate ganyu labour, they are constrained by labour availability. In the life histories, respondents consistently indicated that women are unable to command labour from other sources such as their children; they therefore exclusively depend on their labour for both working on their own farms and for ganyu opportunities. This is in tune with the findings of Leach (1995) which indicated that on average $\mathrm{MHH}$ s had 3.18 workers available for ganyu while FHHs had 2.71. She also found that workers from $\mathrm{MHH}$ s were paid daily rates 38 percent higher than those from FHHs. The paradox, however, is that $\mathrm{FHHs}$ spend more of their labour time on ganyu, but for lower rewards.

The findings of this study show that $\mathrm{FHHs}$ are as diversified as their $\mathrm{MHHs}$ counterparts, but the myriad activities that they are engaged in are often for survival rather than accumulation. This, in turn, undermines their efforts to commercialise agricultural production. The high proportion of smallholder farmers dropping out of agriculture signifies a process of de-agranisation. A disproportionate share of rural households simply cannot make a living out of the land and must complement their efforts to earn a living from alternative livelihood sources. These constraints are pushing households in rural Malawi to straddle agrarian and non-agrarian livelihood activities and/or try to make a living in both agrarian and non-agrarian rural and urban areas (Ellis, 2000; Tsikata, 2015).

The results of this study also demonstrate that women generally play second fiddle in $\mathrm{MHHs}$. This, however, does not happen in a one-size-fits-all manner. We established four different patterns of intra-household dynamics that affect agricultural commercialisation. The dominant pattern involved men making all the decisions and having sole control over productive resources. Life history respondents consistently observed that men made the decisions about crop production. Men also dominated when it came to the disposal of household assets, especially land, and other assets such as household furniture, bicycles, or oxcarts. As one interviewee observed:

At that time, all the decision-making powers in our household were with my father. My mother was simply told what to do and how to do it. This affected our farming as a family because my mother could not voice out her ideas. Our farming was affected because my father could just use proceeds from crop sales any way he wished, without accounting for them. This made planning for the next farming season very difficult. (Life history interview with D1 at Mchaka GHV, T/A Mabvere, Mchinji District, 25 September 2019)

Working Paper 075 | November 2021 
Although both males and females in rural Malawi have low levels of education, males fare better than their female counterparts and tend to exploit their slight advantage in education to assert themselves as the dominant decision-makers in the household (Chinsinga and Matita, 2021). This is further reinforced by cultural constraints that limit the degree of women's engagement with the public domain (Borda-Rodriguez and Vicari, 2014). Women's engagement with the public sphere is limited by societal norms and expectations of being a 'good woman'. Such a woman is devoted to her family and prioritises household maintenance and reproductive functions. These responsibilities are burdensome, yet they are not widely recognised and remunerated as work (ibid.): 'women are passive; they rely for almost everything on their husbands'10.

In the second variant, decision-making is equally dominated by men. They make all decisions at household level unilaterally, but the women challenge their decisions from time to time if they think they are not in the best interest of the household. The women contest their husbands' decisions successfully in some cases and totally fail in others, but 'the most important thing is that we make our feelings known, which forces them [husbands] to make sensible decisions next time'11. Similar sentiments were expressed by a male life history respondent:

I grew up believing that women are subordinates to men. This was what was happening in our household growing up. All the decisions were made by my father. This was my model of household decision-making, but I have been taken by surprise by my wife. She contests almost every decision that I make often in good faith, but I cannot openly admit to her. I am a man. I often adjust silently, sometimes fully considering her views and sometimes with modifications to assert my authority largely still as a man. (Life history interview with D65 at Kamagawa Village, T/A Mabvere, Mchinji District, 10 October 2019)

The third variant is about cooperative decisionmaking at the household level. This involves men and women discussing issues and making decisions jointly. However, it is men who provide leadership in the discussions. Most women respondents emphasised that joint decision-making at the household is key to progressive asset accumulation and hence agricultural commercialisation:

We make decisions about farming together. I have chosen to depart from the old way of doing things because I do not want to infringe her rights as a person. Moreover, we say that the 'know it all' attitude leads to people making costly decisions, which could have otherwise been avoided. We are happy so far and I regard my wife as my mother too. (Life history interview with D60 at Langwani Village, T/A Simphasi, Mchinji District, 10 October 2019)

Though there were not many polygamous households in the sample; the study revealed some interesting dynamics. Decisions about production were difficult in polygamous households because 'cooperation is difficult to achieve among the wives'12. Husbands found it difficult to make binding decisions because 'each wife fights for her own interests and that of her children; life in a polygamous household is not easy'13. Cooperation among wives often becomes unattainable when family size grows. One life history respondent shared her experiences in a polygamous household with three wives. She pointed out that they used to cultivate together in one garden and share the proceeds from crop sales equally. This arrangement collapsed when their children became of age and spoke up: 'our children protested because we were just sharing the proceeds among ourselves without including the children who worked with us' ${ }^{14}$. The women resorted to breaking up the land into three so that each wife could cultivate with her children against the wishes of the husband to maintain it as a single farm.

The results show that men's dominance in decisionmaking regarding production and control of productive resources is universal in rural Malawi. It makes no difference whether the form of residence

10 Life history interview with D50 at Lifiledi Village, T/A Mlonyeni, Mchinji District, 4 October 2019

11 Life history interview with D78 at Chidziko Village, T/A Nthondo, Ntchisi District, 29 October 2019

12 Life history interview with D80 at Chisusu Village, T/A Kapichila, Kasungu District, 12 November 2019

$13 \quad$ lbid

14 Life history interview with D80 at Chisusu Village, T/A Kapichila, Kasungu District, 12 November 2019 
is uxirolocal, virlocal or neolocal. Customarily, women who are 'owners' of land in the uxirolocal form of residence are expected to dominate decision-making processes about land, but this differs in practice. While symbolically women in matrilineal settings have control over land, they are not the principal decision-makers on how to use it (Djurfeldt et al., 2018). The cooperative decision-making variant appears to dominate in the neolocal form of residence, and it is mainly associated with young couples from branching out households. Even more intriguing is the fact that men dominate decision-making processes in $\mathrm{FHHs}$. Women in these households tend to defer decision-making to their older male children and their brothers (see, for example, Chinsinga and Matita, 2021).

The results of the study further caution against the tendency of projecting women as undifferentiated victims of gender inequalities or as heroic survivors against the odds. Tsikata (2015) argues that this tendency reduces complex social relations to oversimplified statements about inequalities and exploitation. The results show that women are not merely passive victims of structures of inequality underpinning gender and intergenerational relations; they also actively defend their interests in which case the contestations over resources does not always favour men. Furthermore, the stress on conflicts among household members downplays the substantial levels of cooperation and shared interests between husbands and wives and household members, and between them and their wider kin (lbid). Recognition of these caveats should lead to more textured and nuanced analysis with transformative policy utility potential.

\subsubsection{Class, wealth and agricultural commercialisation}

The results of the study show that smallholders in rural Malawi are not a homogenous group. They are differentiated into classes shaped by a web of social relations regarding land access, capital, markets, employment opportunities and even social and political status. Smallholder farmers are distinguished into five livelihood trajectories, namely: stepping out, stepping up, hanging in, dropping out and stepping in. Most of the smallholder farmers belong to the hanging in category, with very few belonging to the stepping out and stepping up livelihood categories. $\mathrm{FHHs}$ dominate the hanging in and dropping out livelihood categories. The results further show that the processes of social differentiation are not static, but inherently dynamic. Both hanging in and dropping out households among original and branching out households depend disproportionately on ganyu as a main source of their livelihoods. Strikingly ganyu features prominently as a secondary source of income for stepping up and stepping in households especially among branching out households.

The results show that labour relations mediated through ganyu have been key in shaping class relations in rural Malawi. Several classes exist in this respect: those with the ability to hire ganyu who do not engage in ganyu themselves; those that neither engage in ganyu nor hire ganyu; those who engage in ganyu only when it gets tough (especially in drought or flood situations); and those who engage in ganyu as a routine strategy for their subsistence. The results of the study further show that the proportion of households engaging in ganyu has increased between $2007 / 08$ and 2018/19, especially for the hanging in and dropping out households. This is attributed to inadequate access to productive resources, increasing harsh and unfavourable conditions such as bad weather and market failures and the exploitation by well-off farmers driven by the desire to accelerate their own accumulation. These farmers are predominantly characterised by female headship, poor housing conditions, regular food shortages, lack of productivity enhancing inputs, lack of productive assets such as land and livestock, and reliance on social safety nets. In the life history interviews, most respondents indicated that their pieces of land have become too small to fully provide for their subsistence hence turning to ganyu as a complementary livelihood strategy.

The number of people resorting to ganyu as a complementary livelihood strategy is increasing over the years because most smallholder farmers cannot afford productivity enhancing inputs - especially fertiliser and improved seed. In the life history interviews, most respondents attributed this to 'the disbandment of credit facilities that we used to access through farmers' clubs that helped to produce enough for consumption as well as for sale'15. Credit facilities are no longer readily available to most resource poor farmers following the abandonment of the Smallholder Agricultural Credit Administration (SACA) under the auspices of SAPs. SACA was designed to meet the needs of rural poor people who were excluded from formal financial institutions (Chirwa and Zakeyo, 2004; Chirwa and Matita, 2015). SACA was seen as a logical step in the development of rural banking institutions in Malawi.

Limited access to credit facilities coupled with some other factors such as land fragmentation and worsening 
climatic changes have led to enormous decline in productivity among most farmers. This has forced most of them to resort to ganyu as a complementary livelihood strategy. Partly because of the general worsening livelihoods conditions in rural Malawi, the availability of ganyu is increasingly becoming limited. Yet, the demand for it is increasing as a strategy of last resort for most of the people in rural areas: 'ganyu is no longer readily available because there are not many people who are able to hire ganyu...the majority who are hiring are the stepping in farmers from urban areas'16. $^{\prime 1}$.

The ganyu wage rates have therefore been declining over the years to the detriment of households that rely on it for survival. The findings of the study echo Whiteside's (2000) assertion that the wages from ganyu have been steadily declining since the turn of the 1990s. This decline has particularly disadvantaged $\mathrm{FHHs}$, who relative to $\mathrm{MHHs}$, get lower wages for the same kind of work. Without any alternative source of income, the declining ganyu wages has had negative effects on resource poor farmers' efforts to engage in agricultural commercialisation. The proceeds from ganyu are insufficient to maintain families' subsistence requirements let alone invest in sustainable agricultural intensification or income generating activities (see Smith, 1999; Whiteside, 2000). Moreover, the need to do ganyu to obtain immediate supply of food may conflict with own-farm production and therefore, while addressing an immediate crisis, can lock some households into a vicious cycle of food insecurity hence undermining both short and long-term ambitions for agricultural commercialisation.

The results show that households with assets such as land, oxcarts, farming implements, livestock and operating off farm business enterprises have better prospects for commercialising agriculture than those without. Likewise, compared to $\mathrm{MHH}$, the track record of FHHs owning productive assets is quite dismal, hindering their efforts to commercialise agricultural production. Better off households can augment their landholdings through renting or outright purchases. They can procure productivity enhancing inputs; hire ganyu labour; and invest in appropriate technologies that enhance productivity. The following testimonies from the life histories are illustrative in this regard:

We have been able to do well in agriculture because we have expanded our production through dimba (wetland) cultivation. We can survive the lean period because we rely on harvests from our dimba. This allows us to have enough to sale to raise money for our upland farming. The harvests from dimba are like a bridge that takes us to upland harvest. (Life history interview with D50 at Lifiledi Village, T/A Mlonyeni, Mchinji District, 4 October 2019)

Social and political status is also important in further entrenching class based social differentiation in rural Malawi. Some respondents indicated that they exploited their positions in society to avail of opportunities to accelerate agricultural commercialisation. For example, one respondent reported the benefits of being a lead farmer and a member of the ADMARC liaison committee: 'I have always sold my produce in good time and often at good prices'17. Those connected to or part of royal families reported being privileged in terms of access to critical information and they also dominated leadership positions in community level initiatives. These positions also allowed them to build beneficial connections that have proven useful to agricultural commercialisation efforts both in the short and long-term. These families are further privileged when it comes to accessing land or even in the adjudication of land disputes in which they are involved:

We have plenty of land as a family. It is all because of our connections to the chief's family. Actually, people who have no connections like this were finding it hard to get land unless they rented or bought it, which many cannot afford because it is very expensive. (Life history interview with D18 at Pembele Village, T/A Mlonyeni, Mchinji District, 4 October 2019)

Access to markets is another key determinant for agricultural commercialisation. According to CIAT; World Bank (2018), poor access to agricultural markets, especially for smallholder farmers, not only reduces market participation and commercialisation, but is also a disincentive for farmers to adopt improved technologies. Existing assessments show that market access is a huge challenge in Malawi. It is estimated that only 15 per cent of total produce goes to the market with the remainder used to meet household food requirements. Given limited storage technologies, this aggravates post-harvest losses. Key barriers to market access include poor infrastructure - only 26 per cent of the roads are paved and there is a great deal of price volatility.

Lack of viable markets to spur and sustain agricultural commercialisation was repeatedly echoed by farmers 
in both FGDs and life histories. Farmers attributed this lack of access to liberalisation, which, inter alia, resulted in streamlining ADMARC's activities. ADMARC continues to operate but it no longer serves as a predictable and sustainable market for farmers. This was underlined by the nostalgic references to the role that ADMARC played in marketing farmers' produce in its heyday:

Farming is no longer a reliable source of livelihood for us due to the unreliability of ADMARC. In the good old days, we could plan our farming because we knew we had a guaranteed market. We can no longer do the same with vendors as the main outlet for our produce. (Life history interview with D75 at Mndakalaka Village, T/A Chinkho, Ntchisi District, 12 November 2019)

There is huge potential for smallholder farmers to market their produce through clubs, associations, and cooperatives. Stories about these arrangements were told in both Mchinji and Ntchisi - opportunities for collective marketing abound, especially with large companies that process or manufacture products out of farm produce. In both districts, success stories are almost exclusively linked to NGO or donor efforts to organise farmers as clubs, associations, or cooperatives. The success stories have, however, been rarely maintained beyond the expiry of the projects. There are few success stories about collective marketing initiatives that have emerged organically. The failure of collective marketing initiatives makes it impossible for smallholder farmers to venture into alternative markets rather than relying on vendors even though they are widely condemned as being exploitative. Thus, poor farmer organisation significantly reduces farmer bargaining power and leads to asymmetries in access to market information.

Export markets are a promising alternative but are impeded by stringent quality standards, which are very difficult for Malawian farmers to meet (Chinsinga and Matita, 2021). Both officials and farmers spoke about the Fairtrade arrangement that NASFAM struck with buyers in the UK. Trading as Mchinji Area Smallholder Farmers Association (MASFA), Mchinji farmers exported their groundnuts to the UK between 2007 and 2011 earning premium prices for their produce (Pound et al., 2011). With these proceeds, beneficiary farmers were able to mobilise inputs, hire labour and access extension services that accelerated their agricultural production beyond groundnuts. However, MASFA lost its Fairtrade export certificate because of its failure to keep aflatoxin in the groundnut's exports to acceptable levels (Derlagen and Phiri, 2012).
The agricultural marketing crisis was further deepened by ad hoc export bans for maize and legumes particularly soya beans (Chirwa and Chinsinga, 2015). These export bans are justified as a means to guarantee adequate domestic food supply and stabilise consumer prices. Evidence from Malawi and elsewhere shows that the export bans negatively affect farmers' and traders' incomes by hindering their access to lucrative prices in the international markets (Gustafson, 2016; Makombe, 2016). The unpredictability associated with export bans has therefore undermined the drive toward agricultural commercialisation.

\subsubsection{Social networks, shocks, migration, and agricultural commercialisation}

The results of the study show that social networks, both bonding and bridging, have been very critical in driving or hindering agricultural commercialisation in rural Malawi. Membership to clubs, associations or cooperatives is one of the key drivers of agricultural commercialisation. Farmers belonging to these groups tend to be more commercialised than those who do not, which triggers some form of social differentiation. This was underlined by the fact that most farmers involved in clubs, associations and cooperatives belonged to stepping out, stepping in or stepping up livelihood trajectories. These farmers are privileged in terms of access to information, skills, knowledge, credit, and market access opportunities, which helps them to advance their agricultural production with an eye on commercialisation. Less commercialised farmers are less likely to belong to farmer groups largely due to barriers such as membership fees. These farmers benefit from bonding social networks, but are unable to break into bridging networks, which are vital for expanding their social networks to advance agricultural commercialisation.

Stories were told about how smallholder farmers in rural Malawi have benefited from farmer groups in historical and contemporary contexts. In the life histories, many respondents indicated how clubs were at the centre of agricultural development between the 1970s and 1990s. These clubs served as vehicles for accessing inputs on affordable terms, extension services on a regular basis, and marketing agricultural produce. The following sentiments are illustrative of the role that clubs played in agricultural development:

Farmers' clubs were facilitated by extension workers. Through these clubs, we were able to access inputs, credit, and extension services. These clubs had a very robust structure through which they engaged with farmers on a 
continuous basis resulting in better agricultural performance. (Life history interview with D36 at Nkhwazi Village, T/A Mabvere, Mchinji District, 8 October 2019)

These clubs were generally inclusive from a gender perspective if the basic entry criteria were met. Membership of these clubs was on a family basis 'even though men were the primary representatives for their families'18. The wives could sit in for their families when the men were not available for the scheduled club meetings. If unmarried women met the qualifying criteria, 'they were allowed to be members and they were even elected to leadership positions'19. Some concerns were raised about the negative impact of these clubs on agricultural commercialisation. Farmers were not often at liberty to choose the loan packages that would help them fully realise their potential: 'the loan packages were quite prescriptive, and the magnitude varied according to different crops, which were not necessarily a farmer's priority choice'20. In some cases, smallholder farmers 'were forced to take loan packages for a crop(s) that they did not want to grow'21. Since the clubs used the group collateral philosophy, 'some farmers could block fellow farmers from applying for bigger loan packages, especially when these farmers were deemed not quite trustworthy'22.

Being a lead farmer ${ }^{23}$ and belonging to a chieftaincy family circle were also important. The results show that being a lead farmer opened numerous doors of opportunities, especially in relation to farming. Most lead farmers, for instance, reported being members of ADMARC liaison committees charged with the responsibility of coordinating marketing activities. The committee negotiates prices and resolves any conflict that might arise between ADMARC and farmers. These positions give 'lead farmers opportunity for preferential access to markets for their produce in their capacity as members of the liaison committee...they find it easy to sell their produce than the rest of the farmers'24. Being part of the chiefs' family circle appears to be an added advantage. These families are generally privileged in terms of access to land, access to external resources information, knowledge and skills including assuming leadership positions in matters that generate stakes for the participants. The following sentiments are illustrative in this regard:

I can say we benefitted quite a lot from being part of the chief's extended family... since we had royal ties; our family was favoured in a way. We got information faster than anybody else in the village; we were beneficiaries of almost every form of external assistance to the village; and my father was given various positions of influence in the village. (Life history interview with D50 at Lifiledi Village, T/A Mlonyeni, Mchinji District, 4 October 2019)

The functionality of a marriage consistently came up as a critical prerequisite for sustainable agricultural commercialisation. The results suggest that a stable marriage or family underpinned by a positive web of relationships and strategies is a key driver for asset accumulation and consequent commercialisation. Thus, family farms can only be viable vehicles for agricultural commercialisation if they are run by stable families characterised by healthy relationships. These farms, especially in developing countries, are exclusively reliant on the human resource base of the family reinforced by values of solidarity and long-term commitment. The functionality of marriage and stability of families in rural Malawi are of particular importance because 'in most instances women see marriage as an escape route out of the problems that they experience in their families'25. It was not uncommon to encounter respondents confessing that 'I got married to escape problems that I was experiencing at home, especially after my mother remarried'26.

The results show that successful agricultural commercialisation can be a double-edged sword in terms of family functionality and stability. Successful

18 Life history interview with D100 at Mpofu Village, T/A Chilowoko, Ntchisi District,20 October 2019

$19 \quad$ lbid

20 Life history interview with D120 at Filipo Village, T/A Nthondo, Ntchisi District, 29 October 2019

$21 \quad$ lbid

22 Life history interview with D80 at Chisusu Village, T/A Kapichila, Kasungu District, 12 November 2019

23 A lead farmer is an individual farmer who has been selected by the community to perform technologyspecific farmer-to-farmer extension and are trained in the use of the technology. They act as promoters of technology as well as potential adopters (Khaila et al. 2015).

24 Life history interview with D20 at Sankhulani Village, T/T Simphasi, Mchinji District, 4 October 2019

25 Life history interview with D40 at Mchaka GVH, Mchinji District, 25 September 2019 
agricultural commercialisation can either lead to a happy, stable, and progressive family or it can be destructive to the family altogether:

Getting married helped me in my farming as I found someone to work with and I added more land to cultivate...my husband also supports my farming by providing me with money to buy inputs and pay for labour. (Life history interview with D18 at Dembele Village, T/A Mlonyeni, Mchinji District, 4 October 2019)

My husband has a tendency of marrying many wives. He married three more wives to add to the three he already had. This resulted in poor output of the farm. The first three wives got angry and could no longer work on the farm in protest. They were not happy to be working for other women. As a result, my children lacked the necessities since I had no direct access to the proceeds from the grocery shops as did my first three co-wives. (Life history interview with D19 at Alfred Village, T/A Mlonyeni, Mchinji District, 25 September 2019)

In most cases, the dysfunctionality and instability of family relations occasioned by episodes of successful agricultural commercialisation, ended up in divorce. The results suggest that divorce is an equally doubleedged sword. It can lead to liberty and freedom on the part of women to realise their full potential or it can drive them into destitution. This is often the likely outcome because divorce leads to loss of labour, skills, source of income for inputs and other livelihood necessities. Withdrawal of spousal support often drives FHHs deeper and deeper into poverty (da Corta et al., 2018). Women who escape from abusive relationships through divorce thrive when they are empowered through various mechanisms to earn reliable streams of income. These opportunities are, however, limited because of the multiple disadvantages that women are subjected to in family and community settings.

Both idiosyncratic and covariate shocks have over time constrained and undermined smallholder farmers' efforts to sustain and advance agricultural commercialisation. The main idiosyncratic shocks that households in rural Malawi experience are family illness and death. From the life interviews, these shocks affect households in different ways, but ultimately make it difficult for them to commercialise or to slide back into subsistence. These shocks have led to some households selling their assets to pay off illness and funeral expenses; loss of labour or prolonged periods of inactivity due to chronic illness and taking care of sick family members - a task that falls disproportionately on the shoulders of women - in addition to children dropping out of school due to death or prolonged illness of parents or guardians; and young people, especially girls, being forced into early marriages to escape hardships at home.

The burden of these shocks makes it very difficult for these households to either commercialise or sustain their commercialisation efforts. The following quote highlights the negative impacts of idiosyncratic shocks on agricultural commercialisation:

My father was sick for two years before his death. A lot of money was spent on his treatment while he was in hospital. This made it difficult for me to stay in school. I had no choice but to withdraw from school, yet knowledge is very critical in farming. I believe that my farming experiences would have been different if I had the opportunity to complete at least secondary education. (Life history interview with D70 at Mital-Simeon Village, T/A Kawere, Mchinji District, 8 October 2019)

The results of this study show that idiosyncratic shocks have steadily been aggravated by frequent covariate shocks over the years including droughts, flash floods, pests and diseases affecting especially livestock and the general collapse of produce prices. The main concern consistently echoed was that these shocks were happening with a great deal of regularity, especially since the turn of the 1990s. These shocks, either singularly or in combination, thwart efforts of households to commercialise on a sustainable basis. The main challenge these days is that 'you have either too much rain or prolonged dry spells - drought which occurs rather regularly'27. Households have weathered the impact of droughts or flash floods either through support from social networks or through diversifying their livelihood portfolios.

The effect of migration on smallholder agricultural development is heavily debated in Malawi. While some argue that migration to South African and Zimbabwe negatively affected agricultural development in rural Malawi through shortage of labour, others see migration as spearheading agricultural commercialisation (Whiteside, 2000; Green, 2007). The underlying argument is that the resulting labour shortages in rural Malawi undermined the socio-economic organisation of smallholder production. The life histories in this study demonstrate that labour migration to South Africa and Zimbabwe provided a large boost to smallholder agricultural development in rural Malawi. The workers 
returning from South Africa and Zimbabwe brought with them cash that many of them injected into smallholder agriculture as illustrated by this quote:

My husband went to South Africa to work in the mines. The money he got from there changed our household completely. We bought all the assets we needed as a family and invested massively in agriculture. Since then, we are selfreliant, and we are amongst notable farming households in this community. We always look back at this opportunity of working in South Africa that my husband had as our turning point. (Life history interview with D5 at Thula Village, T/A Nyoka, Mchinji District, 6 October 2019)

Migrant labour to South African mines effectively stopped in the late 1980s dropping from 21,000 in 1987 to under 400 in 1989 (Whiteside, 2000). However, informal migration persists and still accounts for important streams of income and trade that make a huge difference in rural livelihoods (Anderson, 2006). The life histories indicate that migration to Mozambique and Zambia on a seasonal basis remains one of the major survival strategies, especially for households in the Mchinji district. 
This study investigated the processes of change in smallholder farmers' engagement with markets and inherent pathways of commercialisation in rural Malawi through a continuation of qualitative and quantitative methods of inquiry. The study tracked 240 original and their branching off households that were surveyed as part of the 2007/08 FISP evaluation by SOAS et al., (2008) to understand the underlying dynamics of commercialisation over ten-year period. Three data collection techniques were used: the reconnaissance survey that used KIls and FGDs; the quantitative household survey; and life histories of both the original and branching off households. The combination of these tools allowed us to understand the underlying dynamics of commercialisation of smallholder farmers both in a historical and contemporary.

The results of the study show that agricultural commercialisation is a complex process marked by a wide range of cyclic continuities and discontinuities over time. The pattern and rhythm of these continuities and discontinuities are shaped by the overall operative context which involves political, economic, social, and even cultural dimensions. These play a critical role in determining the form, shape and nature of agrarian transformation that takes place. Households in rural Malawi can be distinguished into five possible livelihood trajectories: stepping out, stepping up, hanging in, dropping out, and stepping in. Most households in rural Malawi (both original and branching out households) belong to the hanging in and dropping out categories although the branching out households are slightly better off than the original ones. This could be attributed to the fact that most of the original households have aged and are thereby relatively constrained in terms of labour. The key message from this study is that life in rural Malawi is tough; agriculture is no longer reliable as an exclusive means of subsistence. It has to be supplemented with other livelihood strategies, especially given the rapidly diminishing land per capita and worsening climatic conditions.

The results further show that most households that belong to the stepping out, stepping up and stepping in livelihood trajectories, are predominantly $\mathrm{MHH}$ s with both spouses available. FHHs are clearly outnumbered with most of them belonging to either hanging in or dropping out livelihood trajectories. While there are exceptions, the results of this study demonstrate that $\mathrm{FHHs}$ are subjected to the burden of multiple deprivations and disadvantages. These make it difficult for the FHHs to effectively participate in agricultural commercialisation activities. There is also a great deal of gender and social differentiation manifested through access to, control and land use; asset accumulation, social networks, or capital; and access to markets. FHHs' challenges are exacerbated by cultural norms or expectations that women should be subservient to men, defer to men especially on important decisions, and limit their activities outside the homestead within the neighbourhood unless specifically granted permission. The results of the study show that women and other disadvantaged families are consistently disadvantaged in terms of access to productive resources such as credit, skills and information, social capital, especially in terms of leadership and access to opportunities mediated by external actors.

The dynamics of agricultural commercialisation in rural Malawi have been negatively affected by the triple crisis of land, productivity and marketing. Land tenure security remains uncertain due to an unsettled legislative framework; productivity levels of various crops have remained far below the expected thresholds due to the combination of limited ability to access productivity enhancing inputs, especially seed and fertiliser and worsening climatic conditions; and since the collapse of ADMARC as a reliable marketing outlet, smallholder farmers have found it extremely difficult to sell their produce at a profit. Smallholder farmers have engaged with these challenges in different ways. Some smallholder farmers have sold off their land to the emerging urban farmers; some have found ways of acquiring additional land while still others have figured out how to protect their land by mounting resistance through traditional leaders who enjoy some reverence among the political elite. Smallholder farmers have engaged in diversification of their livelihood portfolio to hedge themselves against declining productivity through, for instance, crop diversification; engaging in off-farm activities; and increasing the acreage of land under winter cultivation. Through often externally driven efforts, smallholder farmers have organised themselves into cooperatives to enhance their 
bargaining powers with buyers of their produce and in the worst-case scenario, they have reacted to the unscrupulous business tendencies of the buyers by offering for sale adulterated produce.

In tandem with insights from the critical agrarian scholarship, the experiences of smallholder farmers in rural Malawi underlie continuity, change and relentless challenges in their efforts to earn their respective livelihoods in a context shaped by both endogenous and exogenous forces. These experiences underpin Berry's (1993) conclusion that no condition is permanent. The experiences of smallholder farmers in rural Malawi reported in this study demonstrate, inter alia, that land tenure systems, access mechanisms, labour and market relations, individual and collective choices, methods and priorities, even communal relationships and social units are in constant state of flux, and subject to some contestation and negotiation according to time and circumstance. Related to this is the fact that rural communities are not homogenous. They experience the same stimuli differently depending mainly on their social and kinship status, material endowment, age and even gender. The experiences also show that these positions are not static. Rural households have the power to alter their fate, but this is largely dependent on how they exercise their agency circumscribed by both endogenous and exogenous forces.

These results underscore the fact that context matters in understanding the dynamics of agricultural commercialisation. The results demonstrate that both politics from below and politics from above are critical in terms of shaping the underlying dynamics of agricultural commercialisation. Policy decisions at the national level are critical to shaping the dynamics of agricultural commercialisation subject to the strategic engagements from local communities depending on the perceived intent of the policies. Local communities are not passive recipients of national policies; they either contest or appropriate them in ways that would promote or safeguard their interests, however, irrational it may appear to the outsiders. These results also draw attention to the question of scale in local level development and transformation. They suggest that it is important to consider a problem at multiple scales, which allows for the possibility to identify the common elements across scales as well as the key features of the problem at each scale. The issue of agricultural commercialisation in rural Malawi, for instance, is shaped by a combination of forces operating at the global, national and local levels. Understanding the dynamics at each of the scales and how they interact would be key to transformative and sustainable solutions to pressing contemporary political, economic, social and even cultural challenges.
We make the following recommendations on the basis of the findings of this study to either promote or enhance the prospects of sustainable smallholder commercialisation in Malawi:

- $\quad$ The triple crisis calls for policy refocusing, reviews and implementation to ensure that these are no longer insurmountable barriers for smallholder farmers to engage in sustainable commercialisation that brings about the desired strategic impact.

- Promoting investment in research and development, extension services and rural infrastructure to ensure that smallholder farmers increase their productivity and are able to seize any opportunities including participating in lucrative produce markets.

- Ensuring that policy interventions are systematically tailored to the needs of different categories of smallholder farmers since they are not a homogenous group. This implies that one-sizefits all policies to promote smallholder agricultural commercialisation are destined to fail.

- Ensuring vertical integration of the smallholder farmers into agri-food value chains, coordination and collective action, stronger market information system, and better access to institutional credit to help smallholder farmers to enhance their productivity and fully take advantage of opportunities in the sector.

- Advancing policy interventions that are gender sensitive and are specifically designed to promote the empowerment of women in the agricultural sector so that they can equally be engaged in agricultural commercialisation. This is imperative because the results of this study show that women are greatly disadvantaged in almost every other aspect.

- Promoting livelihood diversification among smallholder farmers so as to increase their adaptive capacity to the adverse effects of climate change. This should be further supported by improvements in the government's budgetary allocations for climate resilience and adaptation.

The implementation of these policy recommendations should, however, take cognisance of the changes in the overall operative context, which have had a significant impact on land access and ownership, patterns of accumulation and investment, gender, and social differentiation in rural Malawi. The results of this study suggest that agricultural commercialisation is not a significant determinant in shaping and influencing farmers' livelihood trajectories, but it is nonetheless a 
key temporal driver in improving household welfare, housing conditions, and children's education through market participation and engagement. This is the case of unable to participate and engage with lucrative markets on a sustainable basis. The ad hoc nature in which smallholder farmers participate in and engage with markets makes it very difficult to guarantee sustainable poverty escapes and household prosperity as most of the farmers in the two districts are essentially 'hanging in', unable to meet and across production thresholds that would enable them to diversify their livelihood portfolios through agricultural commercialisation and agrarian transformation. Further research should therefore explore how farmers' engagement with markets can be sustained as a driver for sustainable poverty escape beyond just creating a favourable policy milieu supportive of agricultural commercialisation. A related question would be whether in the context of the triple crisis, smallholder agricultural commercialisation in Malawi is sustainable or not. 
Anderson, J. (2006) 'Informal moves, informal markets: International migrants and traders from Mzimba District, Malawi', African Affairs 105(420): 375-397.

Answeeuw, W., Jayne, T., Kachule, R. and Kotsopoulos, J. (2016) 'The Quiet Rise of Medium-Scale Farmers in Malawi', Land MDPI, 5(3): 19. Available at: https://doi.org/10.3390/land5030019 (Accessed:20 August 2020).

Asfaw, S., Catteneo, A., Pallanted, G. and Palma, A. (2017) Impacts of Modifying Malawi's Farm Input Subsidy Programme Targeting. FAO Agricultural Development Economics Working Paper No.5. Rome: Food and Agriculture Organization of the United Nations. Available at: http://www.fao.org/3/a-i7753e.pdf (Accessed: 20 January 2021).

Bernstein, H. (1982) 'Contradictions of the Tanzanian Experience' in S. Jonnes, P. Joshi and M. Murmis (eds.) Rural Poverty and Agrarian Reform. New Delhi: Allied Publishers.

Bernstein, H. (2007) Rural Livelihoods in a Globalising World. Bringing Class Back In. Conference on Policy Intervention and Rural Transformation: Towards a Comparative Sociology of Development, 10-16 September, China Agricultural University, Beijing.

Bernstein, H. (2009) 'V.I Lenin and A.V Chayanov: Looking Back, Looking Forward', The Journal of Peasant Studies 36(1): 55-81.

Berry, S. (1993) No Condition is Permanent: The Social Dynamics of Agrarian Change in Sub-Saharan Africa. Madison: The University of Wisconsin Press.

Bhaduri, A. (1981) 'Class Relations and the Pattern of Accumulation in an Agrarian Economy', Cambridge Journal of Economics 5: 33-46.

Borda-Rodriguez, A. and Vicari, S. (2014) The Malawian Cooperative Movement: Insights from Resilience. IKD Working Paper No. 969, Milton Keynes: The Open University.

Borras, M. (2009) 'Agrarian Change and Peasant Studies: Changes, Continuities and Challenges: An Introduction', The Journal of Peasant Studies 36(1): 5-31.

Bourne, M., Gassner, A., Makui, P. and Muriuki, J. (2017) 'A Network Perspective filling a gap in Assessment of Agricultural Advisory System Performance', Journal of Rural Studies 50: 30-44.

Caulfield, J. (2020) How to do Thematic Analysis. Available at: https://www.scribbr.com/methodology/thematicanalysis/ (Accessed: 4 April 2021).

Chilowa, W. (1991) Structural Adjustment and Poverty: The Case of Malawi. Christiansen Michelsen Institute Working Paper. Bergen, Norway.

Chilowa, W. and Chirwa, E. (1997) 'The Impact of Structural Adjustment Programmes and Human Development', Bwalo: A Forum for Social Development 1: 39-68.

Chimhowu, A. and Woodhouse, P. (2006) 'Customary vs. Private Property Rights? Dynamics and Trajectories of Vernacular Land Markets in Sub-Saharan Africa', Journal of Agrarian Change 6(3): 346-371.

Chimombo, M. (2018) "Failed Promises: The Decline of Cooperative Membership in Malawi", Future Agricultures, 27 September. Available at https://www.future-agricultures.org/blog/failed-promises-the-decline-of-cooperativemembership-in-malawi/(Accessed: 18 October 2020). 
Chinsinga, B. (2002) 'The Politics of Poverty Alleviation in Malawi: A Critical Review', in: H. Englund (ed.), A Democracy of Chameleons: Politics and Culture in New Malawi. Stockholm: Nordiska Africa Institutet, Elander Golab.

Chinsinga, B. (2004) 'Poverty and Food Security in Malawi: Some Policy Reflections on the Context of Crumbling Traditional Support Systems', Canadian Journal of Development Studies 25(2): 321-341.

Chinsinga, B. (2007) Democracy, Decentralisation and Poverty Reduction in Malawi. Cologne: Rudiger Koppe Verlag.

Chinsinga, B. (2008) Exploring the Politics of Land Reforms in Malawi: A Case Study of the Community Based Rural Land Redistribution Programme (CBRLRP). IPPG Discussion Paper Series Number 20. Manchester: University of Manchester.

Chinsinga, B. (2012) The Political Economy of Agricultural Policy Processes in Malawi: A Case Study of the Fertiliser Input Subsidy Programme. FAC Working Paper 39. Brighton, Future Agricultures Consortium. Available at: https://assets.publishing.service.gov.uk/media/57a08a9be5274a31e00006a6/FAC_Working_Paper_039.pdf (Accessed: 10 October 2019).

Chinsinga, B. (2015) 'An Unfinished Agenda in a Neoliberal Context', in: C. Tornimbeni and A. Parroti (eds.) State, Land and Democracy in Southern Africa. London: Ashgate Publishing Limited.

Chinsinga, B. (2018) The Political Economy of Agricultural Commercialisation in Malawi. APRA Working Paper 17. Brighton: Future Agricultures Consortium. Available at: https://opendocs.ids.ac.uk/opendocs/ handle/20.500.12413/14028 (Accessed: 18 July 2020).

Chinsinga, B. and Chasukwa, M. (2015) 'Trapped between the Farm Input Subsidy Programme and the Green Belt Initiative: Malawi's Contemporary Agrarian Political Economy', in: R. Hall, I. Scoones and D. Tsikata (eds.), Africa's Land Rush: Rural Livelihoods and Agrarian Change. London: James Curry.

Chinsinga, B. and Matita, M. (2021) The Political Economy of the Groundnut Value Chain in Malawi: Its Reemergence amidst Policy Chaos, Strategic Neglect, and Opportunism. APRA Working Paper 56. Brighton: Future Agricultures Consortium. Available at: https://opendocs.ids.ac.uk/opendocs/handle/20.500.12413/16679 (Accessed: 10 June 2021).

Chinsinga, B. and Mwalukumo, H. (2021) The Political Economy of Resilience and Adaptation in Malawi: Some Reflective Considerations. Building Resilience and Adapting to Climate Change (BRACC). London: Overseas Development Institute.

Chipande, G. and Vaughan, M. (1986) Women in the Estate Sector of Malawi: The Tea and Tobacco Industries. Switzerland: International Labour Organization.

Chirwa, E. (2008) Land Tenure, Farm Investments and Food Production in Malawi. IPPG Discussion Paper Series No. 18. Manchester: University of Manchester.

Chirwa, E. and Chinsinga, B. (2015) 'The Political economy of Food Price Policy in Malawi, P. Pinstrup-Andersen (ed.) Food Price Policy in an Era of Market Instability: A Political Economy Analysis. Oxford: Oxford University Press.

Chirwa, E. and Dorward, A. (2013) Agriculture Input Subsidies: The Recent Malawi Experience. Oxford: Oxford University Press.

Chirwa, E. and Matita, M. (2015) Space, Market and Employment in Agriculture Development: Malawi Country Report, Research Report No. 45. Cape Town: Institute for Poverty, Land and Agrarian Studies.

Chirwa, E. and Zakeyo, C. (2004) Effects of Economic and Trade Policy Reforms on Food Security in Malawi. Available at: https://eldis.org/document/A58539 (Accessed: 20 June 2019).

Christiansen, R. and Stackhouse, L. (1989) 'The Privatisation of Agricultural Trading in Malawi', World Development 17: 729-740. 
CIAT (International Center for Tropical Agriculture) and World Bank (2018) "Climate-Smart Agriculture in Malawi", CSA Country Profiles for Africa Series. Available at https://ccafs.cgiar.org/resources/publications/climate-smartagriculture-malawi (Accessed: 20 October 2020).

CICRED (Committee for International Cooperation in National Research in Demography) (2007) Rural Populations and Agrarian Transitions in the Global South. CICRED Policy Paper Number 5: Policy Paper Series. CICRED.

Crenshaw, K. (1989) 'Demarginalizing the Intersection of Race and Sex: A Black Feminist Critique of AntiDiscrimination Doctrine and Antiracist Policies', University of Chicago Legal Forum 14: 238-554.

da Corta, L., Scott, L., Eischeletter, M. and Gondwe, A. (2018) Resilience and Sustainable Poverty Escapes in Malawi. London: United States Agency for International Development (USAID) and Overseas Development Institute (ODI).

Derlagen, C. and Phiri, H. (2012) Analysis of Incentives and Disincentives for Groundnuts in Malawi. Technical Notes Series, MAFAP. Rome: Food and Agriculture Organization of the United Nations.

Dickermand, C. and Bloch, P. (1991) Land Tenure and Agricultural Productivity in Malawi. LTIC Paper. Madison: University of Wisconsin.

Djurfeldt, A., Hillborn, E., Mulwafu, W., Mvula, P. and Djurfeldt, G. (2018) "The family farms together, the decisions, however are made by the man' - Matrilineal land tenure systems, welfare and decision making in Rural Malawi', Land Use Policy Vol. 70: 601-610.

Dorward, A. (2009) 'Integrating Contested Aspirations, Processes and Policy: Development as Hanging In, Stepping Up and Stepping Out', Development Policy Review Vol.27: 136-146.

Drazi, W., llikor, J., Kilic, T. and Mrylan, H. (2020) Malawi's Fifth Integrated Household Survey 2019-2020 and Integrated Household Panel Survey 2019. Available at: https://blogs.worldbank.org/opendata/malawis-fifthintegrated-household-survey-2019-2020-and-integrated-household-panel-survey. (Accessed: 23 April 2021).

Ellis, F. (2000) Rural Livelihoods and Diversity in Developing Countries. Oxford: Oxford University Press.

GoM (Government of Malawi) (2000) Agriculture Extension in the New Millennium: Towards Pluralistic and Demand-Driven Services in Malawi. Lilongwe: Ministry of Agriculture and Irrigation.

Green, E. (2007) 'Modern Agricultural History in Malawi: Perspectives on Policy-Choice Explanations', African Studies Review 50(3): 115-133.

Green, E. (2011) 'Agrarian Populism in Colonial and Postcolonial Malawi', African Studies Review 54(3): 143-163.

Gustafson, S. (2016) 'Maize Export Bans Harmful in Malawi', Food Security Portal [online], 7 July. Available at: https://ssa.foodsecurityportal.org/blog/maize-export-bans-harmful-malawi (Accessed: 10 May 2021).

Hall, D. (2011) Powers of Exclusion: Land Dilemmas in Southeast Asia. Honolulu: University of Hawaii Press.

Hamazakaza, P. (undated) Sharing Experiences on Reconnaissance Survey Implementation in Zambia. Zambia: Copperbelt University. Available at: https://www.sentinel-gcrforg/sharing-experiences-reconnaissance-surveyimplementation-zambia (Accessed: 1 April 2021).

Jallow, B. (undated) Sarah Berry, No Condition is Permanent: The Social Dynamics of Agrarian Change in Sub-Saharan Africa. Madison: The University of Wisconsin Press. 1993. Available at: https://www.academia. edu/12001171/Sara_Berry_No_Condition_is_Permanent (Accessed: 23 March 2021).

Jayne, T., Haggblade, S., Mint, N. and Rashid, S. (2011) Synthesis Report Prepared for the African Agricultural Market Programme Policy Symposium. Alliance for Commodity Trade in Eastern and Southern Africa June 20-22, Kigali, Rwanda.

Kambewa, D., Masangano, C., Kakwera, M. and Tchuwa, F. (2018) 'Making Agro-ecosystems work for the Rural Poor', International Journal of Current Research 10(1): 63821-63829. 
Kanyongolo, E. (2005) 'Land Occupations in Malawi: Challenging the Neoliberal Order', in: S. Moyo and P. Yeros (eds.), Reclaiming the Land: The Resurgence of Rural Movements in Africa, Asia and Latin America. London and New York: Zed Books.

Kay, C. (2009) 'Development Strategies and Rural Development: Exploring Synergies', The Journal of Peasant Studies 36(1): 103-137.

Kazembe, C. and Prizzon, G. (2019) 'Analysis of ACE's Warehouse Receipts and Market Information System: An IFPRI-ACE Dissemination Event', IFPRI Malawi, 13 December. Available at: https://www.ifpri.org/blog/ analysis-aces-warehouse-receipts-and-market-information-systems-ifpri-ace-dissemination-event (Accessed: 25 January 2020).

Kerkvliet, B. (2009) 'Everyday Politics in Peasant Societies and (and ours)', The Journal of Peasant Studies 36(1): 227-243.

Kishindo, P. (1997) Land Tenure: The Case of the Salima District, Central Malawi, Malawi Journal of Social Science 16: 57-67.

Kishindo, P. (2004) 'Customary Land Tenure and the New Land Policy in Malawi', Journal of Contemporary African Studies 22(22): 213-225.

Kydd, J. (1984) Malawi in the 1980s: Development Policies and Economic Change: Malawi: An Alternative Pattern of Development. Edinburgh: Centre of African Studies.

Maguire, M. and Delahunt, B. (2017) ‘Doing a Thematic Analysis: A Practical Step-by-Step Guide for Learning and Teaching Scholars', All Ireland Journal of Teaching and Learning in Higher Education 8(3): 3351-33514.

Mangani, R., Jayne, T., Hazel, P., Muyanga, M., Chimatiro, S., Burke, W. and Johnson, M. (2020) Agricultural Transformation to Action. MwAPATA Institute Working Paper No. 20/01. Lilongwe: MwAPATA Institute.

Masangano, C. and Mthinda, C. (2012) Pluralistic Extension System in Malawi. IFPRI Discussion Paper 1171. Washington DC: International Food Policy Research Institute.

Masanjala, W. (2006) 'Crop Liberalisation and Poverty Alleviation in Africa: Evidence from Malawi', Agricultural Economics 35: 231-240.

Matita, M., Chirwa, E., Kaiyatsa, S., Mazalale, J., Chimombo, M., Mgalamadzi, L. and Chinsinga, B. (2021) Determinants of Smallholder Farmers' Livelihood Trajectories: Evidence from Rural Malawi. APRA Working Paper 50. Brighton: Future Agricultures Consortium. Available at: https://opendocs.ids.ac.uk/opendocs/ handle/20.500.12413/16479 (Accessed: 20 August 2021).

Mkandawire, R. (1984) 'Customary Land, the State and Agrarian Change in Malawi: The Case of Chewa Peasantry in Lilongwe Rural Development Project', Journal of Contemporary African Studies 3(1): 109-128.

Muyanga, M., Nyirenda, Z., Lifeyo, Y. and Burke, W. (2020) The Future of Smallholder Farming in Malawi. MwAPATA Institute Working Paper No. 20/03. Lilongwe: MwAPATA Institute.

Ng'ong'ola, C. (1982) 'The Design and Implementation of Customary Land Reforms in Central Malawi', Journal of African Law 26(2): 115-132.

Nkhoma, P. (2018). 'The evolution of agricultural input subsidy programs: contextualizing policy debates in Malawi's FISP', World Development Perspectives, 9: 12-7.

NSO (National Statistics Office) (2019) Malawi Population and Housing Census: Main Report. Zomba: NSO.

Olofsson, M. (2020) 'Socio-economic differentiation from a Class Analytic Perspective: The Case of Smallholder Tree-Crop Farmers in Limpopo, South Africa', Journal of Agrarian Change 20: $37-59$.

Orama, J. and Wijeratna, A. (2014) A Seat at the Table? Ensuring Smallholder Farmers are Heard in Public-Private Partnerships. London: Fairtrade Foundation.

Oya, C. (2010) 'Agro-pessimism, Capitalism and Agrarian Change: Trajectories and Contradictions in SubSaharan Africa', in: V. Padayachee (ed.), Political Economy of Africa. London: Routledge. 
Palacio-Lopez, A. and Lopez, R. (2015) 'The Gender Gap in Agricultural Productivity: The Role of Market Imperfections', Journal of Development Studies 51(9): 1175-1192.

Peters, P. (2004) 'Inequality and Social Conflict over Land in Africa', Journal of Agrarian Change 4(3): 269-314.

Peters, P. and Kambewa, D. (2007) 'Whose Security? Deepening Social Conflict over 'Customary' Land in the Shadow of Land Tenure Reform in Malawi', The Journal of Modern African Studies 45(3): 447-472.

Poulton, C. (2017) "What is Agricultural Commercialisation, why is it important, and how do we measure it?" APRA Working Paper 6. Brighton: Future Agricultures Consortium. Available at: https://opendocs.ids.ac.uk/opendocs/ handle/20.500.12413/13560 (Accessed: 24 May 2020).

Poulton, C. and Chinsinga, B. (2018) The Political Economy of Agricultural Commercialisation in Africa. APRA Working Paper 16. Brighton: Future Agricultures Consortium. Available at: https://opendocs.ids.ac.uk/opendocs/ handle/20.500.12413/14027 (Accessed: 29 September 2020).

Pound, B., Olok, F., Phiri, A. and Ranger, R. (2011) Branching Out: Fairtrade: Monitoring the Impact of Fairtrade on Certified Organisation. Available at: https://www.fairtrade.net/library/branching-out-fairtrade-in-malawimonitoring-the-impact-of-fairtrade-on-five-certified- (Accessed: 13 February 2019).

Prowse, M. and Grassin, P. (2020) Tobacco, Transformation and Development Dilemmas from Central Africa. London: Palgrave Macmillan.

Scoones, I. (2009) 'Livelihoods Perspectives and Rural Development', The Journal of Peasant Studies 36(1): 171196.

Smith, W. (1999) Safety nets in Malawi-how much for how many? Lilongwe: World Bank.

Sobel, J. (2002) 'Can We Trust Social Capital?’ Journal of Economic Literature 40(1): 139-154.

SOAS (School of Oriental and African Studies), Wadonda Consult, Overseas Development Institute (ODI) and Michigan State University (2008) Evaluation of the 2006/7 Agricultural Input Supply Programme, Malawi: Final Report. London: SOAS.

Speijer, T. (2016) Agrarian Transitions in Ghana: Exploring Changes at the Level of Gender Relations. Wageningen: University of Wageningen.

Ssali, S., Theobald, S. and Hawkins, K. (2015) Life Histories: A Research Method to Capture People's Experiences of Health Systems in Post-Conflict Countries. Available at: https://healthsystemsglobal.org/news/life-histories-aresearch-method-to-capture-peoples-experiences-of-health-systems-in-post-conflict-countries/ (Accessed: 4 April 2021).

Takane, T. (2008) 'Customary Land Tenure, Inheritance Rules, and Smallholder Farmers in Malawi', Journal of Southern Africa Studies 34(2): 269-291.

Thomas, D., Witoelar, F., Frankenberg, E., Sikoki, B., Straus, J., Sumantri, C. and Suriastin, W. (2012) 'Cutting the Costs of Attrition: Results from the Indonesia Family Life Survey', Journal of Development Economics 98(1): 108-123.

Tsikata, D. (2015) The Social Relations of Agrarian Change. Working Paper. Rome: Food and Agriculture Organization of the United Nations (FAO), International Institute for Environment and Development (IIED), Institute of Development Studies (IDS) and Overseas Development Institute (ODI).

UN Women, World Bank, UNEP (UN Environment Programme) and UNDP (UN Development Programme) (2015) The Cost of the Gender Gap in Agricultural Productivity in Malawi, Tanzania and Uganda. New York UN Women, UNDP, UNEP and the World Bank.

Whiteside, M. (2000) Ganyu Labour in Malawi and its Implications for Livelihood Security Interventions: An Analysis of Recent Literature and Implications for Poverty Alleviation. Network Paper No.99. London: ODI Agricultural Research and Extension Network (AgREN).

World Bank (2010) World Development Report 2010: Development and Climate Change. Washington DC: The World Bank. 
Citation: Chinsinga, B., Matita, M., Chimombo, M., Msofi, L., Kaiyatsa, S. and Mazalale, J. (2021) Agricultural Commercialisation and Rural Livelihoods in Malawi: A Historical and Contemporary Agrarian Inquiry. APRA Working Paper 75. Brighton: Future Agricultures Consortium

\section{(cc) BY-NC-ND}

This is an Open Access report distributed under the terms of the Attribution-Non Commercial-No Derivs 4.0 Unported (CC BY-NC-ND 4.0) Attribution - You must give appropriate credit, provide a link to the license, and indicate if changes were made. You may do so in any reasonable manner, but not in any way that suggests the licensor endorses you or your use. NonCommercial — You may not use the material for commercial purposes. NoDerivatives - If you remix, transform, or build upon the material, you may not distribute the modified material. You are free to: Share - copy and redistribute the material in any medium or format.

https://creativecommons.org/licenses/by-nc-nd/4.0/legalcode

If you use the work, we ask that you reference the APRA website (www.future-agricultures.org/apra/) and send a copy of the work or a link to its use online to the following address for our archive: APRA, Future Agricultures Consortium, University of Sussex, Brighton BN1 9RE, UK (apra@ids.ac.uk)

All APRA Working Papers go through a review process before publication.

\section{Cc. Creative}

\section{DO YOU HAVE COMMENTS ON THIS PAPER?}

We would welcome your feedback on this working paper!

To provide brief comments, please follow this link to our short APRA Working Paper Feedback form: https://goo.gl/forms/1iVnXhhrIGesfR9

Agricultural Policy Research in Africa (APRA) is a programme of the Future Agricultures Consortium (FAC) which is

generating new evidence and policy-relevant insights on more inclusive pathways to agricultural commercialisation in sub-Saharan Africa. APRA is funded with UK aid from the UK Foreign, Commonwealth \&

\section{Development Office (FCDO) and will run from 2016-2022.}

The APRA Directorate is based at the Institute of Development Studies (IDS), UK (www.ids.ac.uk), with regional hubs at the Centre for African Bio-Entrepreneurship (CABE), Kenya, the Institute for Poverty, Land and Agrarian Studies (PLAAS), South Africa, and the University of Ghana, Legon. It builds on more than a decade of research and policy engagement work by the Future Agricultures Consortium (www.future-agricultures.org) and involves more than 100 researchers and communications professionals in Africa, UK, Sweden and USA. 